\title{
Remote sensing of macrophyte morphological traits: Implications for the management of shallow lakes
}

\author{
Paolo VILLA, ${ }^{1 *}$ Monica PINARDI, ${ }^{1,2}$ Viktor R. TÓTH, ${ }^{3}$ Peter D. HUNTER, ${ }^{4}$ Rossano BOLPAGNI, ${ }^{2}$ \\ Mariano BRESCIANI ${ }^{1}$
}

${ }^{1}$ Institute for Electromagnetic Sensing of the Environment, National Research Council, Via Bassini 15, 20133 Milan, Italy; ${ }^{2}$ Department of Chemistry, Life Sciences and Environmental Sustainability, University of Parma, V.le Usberti 11/A, 43124 Parma, Italy; ${ }^{3}$ Balaton Limnological Institute Centre for Ecological Research, Hungarian Academy of Sciences, Tihany, Hungary; ${ }^{4}$ Biological and Environmental Sciences, School of Natural Sciences, University of Stirling, Stirling, United Kingdom

*Corresponding author: villa.p@irea.cnr.it

\begin{abstract}
Macrophytes are important elements of freshwater ecosystems, fulfilling a pivotal role in biogeochemical cycles. The synoptic capabilities provided by remote sensing make it a powerful tool for monitoring aquatic vegetation characteristics and the functional status of shallow lake systems in which they occur. The latest generation of airborne and spaceborne imaging sensors can be effectively exploited for mapping morphologically - and physiologically - relevant vegetation features based on their canopy spectral response. The objectives of this study were to calibrate semi-empirical models for mapping macrophyte morphological traits (i.e., fractional cover, leaf area index and above-water biomass) from hyperspectral data, and to investigate the capabilities of remote sensing in supporting macrophyte monitoring and management. We calibrated spectral models using in situ reflectance and morphological trait measures and applied them to airborne hyperspectral imaging data, acquired over two shallow European water bodies (Lake Hídvégi, in Hungary, and Mantua lakes system, in Italy) in two key phenological phases. Maps of morphological traits were produced covering a broad range of aquatic plant types (submerged, floating, and emergent), common to temperate and continental regions, with an error level of $5.4 \%$ for fractional cover, $0.10 \mathrm{~m}^{2} \mathrm{~m}^{-2}$ for leaf area index, and $0.06 \mathrm{~kg} \mathrm{~m} \mathrm{~m}^{-2}$ for abovewater biomass. Based on these maps, we discuss how remote sensing could support monitoring strategies and shallow lake management with reference to our two case studies: i.e., by providing insight into spatial and species-wise variability, by assessing nutrient uptake by aquatic plants, and by identifying hotspot areas where invasive species could become a threat to ecosystem functioning and service provision.
\end{abstract}

Key word: Biomonitoring; fractional cover; LAI; biomass; invasive species; hyperspectral data; APEX.

\section{INTRODUCTION}

Macrophytes are important elements of freshwater ecosystems (Jeppesen et al., 1997), performing multiple ecosystem services (e.g., carbon sequestration, habitat provision, nutrient uptake) and fulfilling a pivotal role in the cycling of elements in aquatic ecosystem (e.g., $\mathrm{C}$ and gas fluxes; denitrification in sediment) (Wetzel, 1992; Schriver et al., 2005; Bolpagni et al., 2007; Jordan et al., 2011; Boerema et al., 2014; Castaldelli et al., 2015). Under current climate warming scenarios, an alteration in macrophyte ecological status and abundance is predicted in wetlands and shallow lakes (Poff et al., 2002; Dudgeon et al., 2006). In particular, increasing nutrient loading, water consumption and climate change effects are expected to lead to a rapid spread of opportunistic and floating species in macrophyte abundant systems (McKee et al., 2002; Kosten et al., 2011; Bolpagni et al., 2015; Bolpagni and Piotti, 2016). In this context, excessive growth of invasive macrophyte meadows needs to be effectively monitored in order to inform management actions to mit- igate negative effects on shallow inland water ecosystems, such as risk of anoxia (Goodwin et al., 2008, Hestir et al., 2008). Furthermore, the multiple anthropogenic uses of water (e.g., water supply, irrigation, fishing, and hydropower) have greatly intensified pressure on freshwater ecosystems (MEA, 2005). This drastic and rapid shift in environmental conditions can have profound effects on macrophyte species resulting in marked changes in the structure and function of ecosystems, increased vulnerability to further perturbation (Steffen et al., 2006; Metzger et al., 2006) and a need for sound, evidence-based ecosystems management. In response, more restrictive chemical and biological monitoring standards for inland waters have been introduced (e.g., the EU Water Framework Directive; European Union, 2000), but the resources available for monitoring programmes, and in particular for in situ sampling, are constantly decreasing.

In this context, remote sensing could be a beneficial tool to complement and extend in situ measurements, providing frequent, internally-consistent and spatially synoptic observations both for near real-time and retrospective 
analyses (Adam et al., 2010; Birk and Ecke, 2014). Although many scientific and technological advancements have taken place during recent decades, the potential of remote sensing for ecological applications is still dramatically under-exploited, especially by end-users in charge of environmental monitoring (Bukata, 2005; Schaeffer $e t$ al., 2013; Palmer et al., 2015). The biological complexity and high temporal variability of freshwater ecosystems are the main reasons why remote sensing techniques are not yet fully operational in water quality monitoring and in the assessment of aquatic vegetation abundance and phenology. New spaceborne and airborne sensors, either multi- or hyper-spectral, an increasing volume of open and low cost remotely sensed data, and the development of simple straightforward processing approaches are now changing this scene. For instance, the spectral response features of macrophytes have been exploited in freshwater ecosystems for a range of applications (i.e., mapping aquatic plant species and functional groups, Hestir et al., 2008, Hunter et al., 2010; monitoring vegetation status, Bresciani et al., 2009; Villa et al., 2013; assessing plant ecophysiology, Stratoulias et al., 2015; and estimating plant morpho-physiological parameters, Penuelas et al., 1993). In particular, flexible and straightforward approaches based on spectral indices (SIs) have gained scientific and operational recognition for analysing vegetation from remote sensing data. SIs rely on the identification of key spectral wavebands - related to specific physiological and structural characteristics of plants combined into algebraic indices, which are implemented using empirical or semi-empirical methods to estimate vegetation dynamics and parameters (e.g., vigour or greenness, leaf area index, fractional cover, density, biomass, and the fraction of absorbed photosynthetically active radiation) (Asrar et al., 1989; Goward and Huemmrich, 1992; Penuelas et al., 1993; Gitelson and Merzlyak, 1996; Haboudane et al., 2004). Most of the studies on this topic, and especially on the use of spectral information and SIs to estimate and map vegetation morphological traits, are still based on terrestrial vegetation and agricultural crops (e.g., Rouse et al., 1974; Tucker et al., 1979; Huete, 1988; Gobron et al., 2000; Broge and Leblanc, 2001; Dash and Curran, 2004; Haboudane et al., 2004; Tian et al., 2005; Gitelson et al., 2006; Wu et al., 2009; Hunt et al., 2011; Maccioni et al., 2011).

There is a need to extend the investigation and further test the efficiency of SIs-based models for aquatic plants, which are known to exhibit different spectral and temporal features compared to terrestrial vegetation (Silva et al., 2008; Adam et al., 2010; Villa et al., 2014, 2015). Considering the importance of aquatic vegetation to freshwater biogeochemical processes and the unfavourable conservation status of many inland ecosystems globally, the capabilities of remote sensing for assessing macro- phyte characteristics and the functional status of shallow systems dominated by macrophytes are in fact still scarcely exploited or not fully investigated (Ribaudo et al., 2010; Jacobs and Harrison, 2014).

In this study, we focused on filling this gap by demonstrating the great potential of remote sensing for mapping macrophyte morphological traits, by testing and adapting SI-based models that make use of information about canopy spectral features in the visible to near infrared range. To this end, we analysed airborne hyperspectral imaging data acquired over two shallow European water bodies (Lake Hídvégi, in Hungary, and Mantua lakes system, in Italy), hosting abundant and diverse macrophyte communities comprising submerged, floating and emergent species, in two critical phases of their growing season: middle of July and late September, corresponding to the maximum growth peak and the end phase of growth, shortly before the senescence period. The two areas are also representative of two different water management strategies, and represent paradigmatic case studies of macrophyte management: i) Lake Hídvégi is part of the Kis-Balaton Water Protection System, in western Hungary, which serves to retain nutrients and particulate matter carried by the River Zala before it enters Lake Balaton (the largest lake in Central Europe); and ii) the Mantua lakes system, a group of three eutrophic shallow fluvial lakes in Northern Italy, where the abundant vegetation is periodically cut and taken away to minimize the possibility of negative consequences on the ecosystem (e.g., risk of hypoxia, lakes infilling), and promote nutrient removal from the system.

The main objectives of our analysis were: i) to calibrate simple semi-empirical models for estimating and mapping macrophyte morphological traits (fractional cover, leaf area index and above-water biomass) from hyperspectral imaging data over a range of plant types, and ii) to investigate and demonstrate the capabilities of remote sensing data and products in supporting monitoring strategies and shallow lakes management.

\section{METHODS}

\section{Study sites}

The study sites were two temperate European shallow lakes with connected wetlands and abundant macrophyte cover, mainly consisting of floating and emergent species: Lake Hídvégi (Hungary) and Mantua lakes system (Italy).

Lake Hídvégi $\left(46^{\circ} 38^{\prime}\right.$ N, $17^{\circ} 08^{\prime}$ E; Fig. 1) is part of the Kis-Balaton Water Protection System $\left(\sim 81 \mathrm{~km}^{2}\right.$; max depth $2 \mathrm{~m}$ ), a semi-artificial wetland area located immediately upstream of the main inflow into Lake Balaton from the River Zala (which supplies $45 \%$ of the water input and $35-40 \%$ of nutrient load to Lake Balaton; 
Kovács et al., 2010). Kis-Balaton (or "Small Balaton") was originally the westernmost basin of the lake. Due to intense sediment deposition from the Zala, Kis-Balaton was the shallowest basin, largely dominated by Phragmites australis (Cav.) Trin. ex Steud., and other aquatic macrophytes, but with substantial open water areas. Through time, Kis-Balaton was partially drained and later disconnected from Lake Balaton. In 1979, the Kis-Balaton Water Protection System (KBWPS) was built to facilitate sedimentation and nutrient removal from the River Zala (Istvánovics et al., 2007). The KBWPS is composed of two areas: i) an open-water reservoir, Lake Hídvégi ( 18 $\mathrm{km}^{2}$, mean retention time 40 da ys; water inflow $175 \times 10^{6}$ $\mathrm{m}^{3} \mathrm{y}^{-1}$; Fig. 1) with the main function of retaining inorganic nutrients and total suspended solids carried by the Zala; ii) a marshland with 95\% helophyte coverage (P. australis and Carex ssp. meadows; Tátrai et al., 2000), that plays an important role in the nutrient filtration process as shown by Dömötörfy et al. (2003). At the local scale, the shallow eutrophic Lake Hídvégi is colonized by floating-leaved macrophytes, with dense Trapa natans L. beds, as well as Nuphar lutea (L.) Sm., and Nymphaea alba L. populations (Dömötörfy et al., 2003; Dinka et al., 2008), and by submerged species in some littoral zones (Ceratophyllum demersum L., and Najas marina L.).
The Mantua lakes system is a fluvial system $\left(45^{\circ} 10^{\prime}\right.$ N, $10^{\circ} 47^{\prime}$ E; Fig. 1) composed of three eutrophic shallow lakes and two protected wetland areas, surrounding the city of Mantua, in Northern Italy. The Vasarone dam, built in 1190 A.D. along the River Mincio, and other downstream weirs determined the formation of the three Mantua Lakes $\left(\sim 6.1 \mathrm{~km}^{2}\right.$; mean depth $\left.\sim 3.5 \mathrm{~m}\right)$ and of the "Valli del Mincio" $\left(\sim 12.7 \mathrm{~km}^{2}\right)$ and "Vallazza" $\left(\sim 5.0 \mathrm{~km}^{2}\right)$ wetlands, located upstream and downstream, respectively. Common reed dominates the shorelines and a large portion ( $40 \%$ of total surface) of the "Valli del Mincio" wetland (Tomaselli et al., 2000), and dense meadows of $N$. lutea, T. natans, and Nelumbo nucifera Gaertn. are present in littoral and open water areas during the vegetative period (April-October). Less frequent but still present in localized littoral areas are N. alba and Ludwigia hexapetala (Hook. \& Arn.) Zardini, H.Y. Gu \& P.H. Raven stands. Free-floating (e.g., Azolla filiculoides Lam. and Lemna spp.) and submerged macrophytes (mainly $C$. demersum) can seasonally colonize littoral zones and areas where the water flow is low. In the last few decades, the progressive eutrophication of the fluvial lake system has favoured a marked proliferation of opportunistic primary producers (phytoplankton and emerging or floating macrophytes) with effects also on the benthic system (e.g., lake infilling,

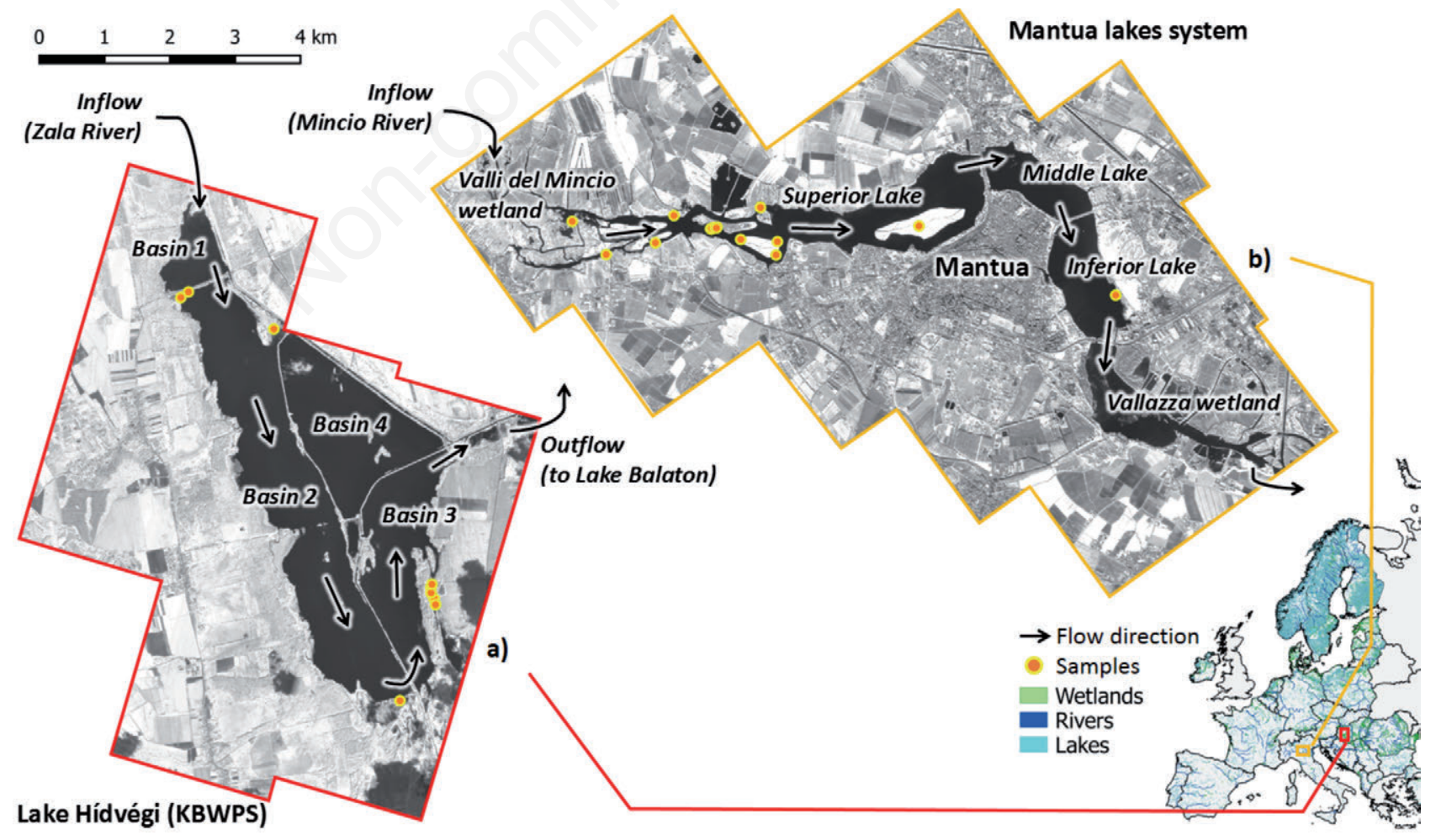

Fig. 1. Study sites and location of macrophyte plot sampled. a) Lake Hídvégi. b) Mantua lakes system. 
hypoxia) (Pinardi et al., 2011). In particular, the development of invasive meadows of emerging and floatingleaved macrophytes (e.g., N. nucifera and T. natans) in periods of high water temperature, nutrient availability and stable weather conditions, has required management intervention by local authorities to control plant growth and to preserve ecosystem services, including water utility (Pinardi et al., 2011, 2015).

\section{In situ and laboratory data}

In situ data were collected during boat-based surveys in Lake Hídvégi (16-18 July 2014) and Mantua lakes system (26 June and 23 September 2014, 16 and 31 July 2015), over a total of 26 plots covering 7 species (C. demersum - CD, N. marina - NM, A. filiculoides - AF,
$N$. lutea - NL, N. alba - NA, T. natans - TN, N. nucifera $\mathrm{NN})$. Each plot represents an area of minimum $10 \times 10 \mathrm{~m}$ homogeneous vegetation cover around the sampling locations, represented by a dominant species. Tab. 1 lists the main characteristics and parameters collected from each sampled macrophyte plot.

In situ macrophyte canopy spectral response data were acquired using portable high-resolution spectroradiometers (ASD FieldSpec Pro FR and Spectral Evolution SR3500). Ten replicate measurements were acquired per plot from adaxial surfaces at nadir. Measurement height above the plot was approximately $50 \mathrm{~cm}$ and the instrument field of view was $25^{\circ}$ (i.e., sampling an area of $20-25 \mathrm{~cm}$ diameter). Reflectance spectra were obtained by calculating the ratio between radiance recorded from each sample and radiance acquired for a white reflectance standard (Spectralon white

Tab. 1. Summary of the in situ data on macrophyte abundance and morphological traits collected at the two study sites: fractional cover (fC), leaf area index (LAI) and biomass $\left(\right.$ Biom $\left._{\text {drv }}\right)$.

\begin{tabular}{|c|c|c|c|c|c|c|}
\hline Study site & $\begin{array}{l}\text { Sample } \\
\text { date }\end{array}$ & $\begin{array}{c}\text { Sample } \\
\text { ID }\end{array}$ & Species & Functional group & $\begin{array}{l}\text { Coordinates } \\
\text { (Lat, Lon) }\end{array}$ & $\begin{array}{c}\text { Morphological } \\
\text { traits }\end{array}$ \\
\hline \multicolumn{7}{|c|}{ Lake Hídvégi (KBWPS) } \\
\hline & $16 \mathrm{Jul} 2014$ & CD1 & Ceratophyllum demersum & Submerged & $46.6154 \mathrm{~N}, 17.1678 \mathrm{E}$ & $\mathrm{fC}^{*}\left(\mathrm{LAI}^{*}\right), \mathrm{Biom}_{\mathrm{dry}}{ }^{*}$ \\
\hline & 16 Jul 2014 & NA1 & Nymphaea alba & Floating-leaved & $46.6146 \mathrm{~N}, 17.1672 \mathrm{E}$ & fC, LAI, Biom dry $_{1}$ \\
\hline & 16 Jul 2014 & NA2 & Nymphaea alba & Floating-leaved & $46.6141 \mathrm{~N}, 17.1676 \mathrm{E}$ & fC, LAI, Biom ${ }_{\text {dry }}$ \\
\hline & 16 Jul 2014 & NL1 & Nuphar lutea & Floating-leaved & $46.6149 \mathrm{~N}, 17.1674 \mathrm{E}$ & fC, LAI, Biom ${ }_{\text {dry }}$ \\
\hline & 18 Jul 2014 & NM1 & Najas marina & Submerged & $46.6589 \mathrm{~N}, 17.1238 \mathrm{E}$ & $\mathrm{fC}^{*}\left(\mathrm{LAI}^{*}\right), \mathrm{Biom}_{\mathrm{dry}} *$ \\
\hline & 16 Jul 2014 & TN1 & Trapa natans & Floating & $46.5998 \mathrm{~N}, 17.1593 \mathrm{E}$ & fC, LAI, Biom ${ }_{\text {dry }}$ \\
\hline & 16 Jul 2014 & TN2 & Trapa natans & Floating & $46.6146 \mathrm{~N}, 17.1671 \mathrm{E}$ & fC, LAI, Biom ${ }_{\text {dry }}$ \\
\hline & 18 Jul 2014 & TN3 & Trapa natans & Floating & $46.6525 \mathrm{~N}, 17.1425 \mathrm{E}$ & fC, LAI, Biom ${ }_{\text {dry }}$ \\
\hline & 18 Jul 2014 & $\mathrm{TN} 4$ & Trapa natans & Floating & $46.6586 \mathrm{~N}, 17.1235 \mathrm{E}$ & $\mathrm{fC}, \mathrm{LAI}, \mathrm{Biom}_{\mathrm{dry}}$ \\
\hline \multicolumn{7}{|c|}{ Mantua Lakes system } \\
\hline & 26 Jun 2014 & AF1 & Azolla filiculoides & Free-floating & $45.1589 \mathrm{~N}, 10.7235 \mathrm{E}$ & fC, LAI, Biom ${ }_{\text {dry }}$ \\
\hline & 23 Sep 2014 & CD1 & Ceratophyllum demersum & Submerged & $45.1636 \mathrm{~N}, 10.7440 \mathrm{E}$ & $\mathrm{fC}^{*}\left(\mathrm{LAI}^{*}\right), \mathrm{Biom}_{\mathrm{dry}}{ }^{*}$ \\
\hline & 26 Jun 2014 & NA1 & Nymphaea alba & Floating-leaved & $45.1572 \mathrm{~N}, 10.7138 \mathrm{E}$ & fC, LAI, Biom ${ }_{\text {dry }}$ \\
\hline & 26 Jun 2014 & NL1 & Nuphar lutea & Floating-leaved & $45.1619 \mathrm{~N}, 10.7074 \mathrm{E}$ & fC, LAI, Biom ${ }_{\text {dry }}$ \\
\hline & 23 Sep 2014 & NL2 & Nuphar lutea & Floating-leaved & $45.1608 \mathrm{~N}, 10.7342 \mathrm{E}$ & fC, LAI, Biom dry $_{1}$ \\
\hline & 16 Jul 2015 & NL3 & Nuphar lutea & Floating-leaved & $45.1608 \mathrm{~N}, 10.7343 \mathrm{E}$ & fC, LAI, Biom dry $_{1}$ \\
\hline & 31 Jul 2015 & NL4 & Nuphar lutea & Floating-leaved & $45.1608 \mathrm{~N}, 10.7342 \mathrm{E}$ & fC, LAI, Biom dry $_{\text {. }}$ \\
\hline & 26 Jun 2014 & NN1 & Nelumbo nucifera & Emergent & $45.1626 \mathrm{~N}, 10.7270 \mathrm{E}$ & fC, LAI, Biom ${ }_{\text {dry }}$ \\
\hline & 23 Sep 2014 & NN2 & Nelumbo nucifera & Emergent & $45.1610 \mathrm{~N}, 10.7748 \mathrm{E}$ & fC, LAI, Biom dry $_{\text {. }}$ \\
\hline & 16 Jul 2015 & NN3 & Nelumbo nucifera & Emergent & $45.1593 \mathrm{~N}, 10.7399 \mathrm{E}$ & fC, LAI, Biom dry $_{\text {. }}$ \\
\hline & 16 Jul 2015 & NN4 & Nelumbo nucifera & Emergent & $45.1569 \mathrm{~N}, 10.7472 \mathrm{E}$ & fC, LAI, Biom dry \\
\hline & 16 Jul 2015 & NN5 & Nelumbo nucifera & Emergent & $45.1590 \mathrm{~N}, 10.7475 \mathrm{E}$ & fC, LAI, Biom ${ }_{\text {dry }}$ \\
\hline & 26 Jun 2014 & TN1 & Trapa natans & Floating & $45.1609 \mathrm{~N}, 10.7351 \mathrm{E}$ & fC, LAI, Biom ${ }_{\text {dry }}$ \\
\hline & 23 Sep 2014 & TN2 & Trapa natans & Floating & $45.1608 \mathrm{~N}, 10.7353 \mathrm{E}$ & fC, LAI, Biom ${ }_{\text {dry }}$ \\
\hline & 23 Sep 2014 & TN3 & Trapa natans & Floating & $45.1510 \mathrm{~N}, 10.8130 \mathrm{E}$ & fC, LAI, Biom dry $_{\text {. }}$ \\
\hline & 16 Jul 2015 & TN4 & Trapa natans & Floating & $45.1607 \mathrm{~N}, 10.7354 \mathrm{E}$ & fC, LAI, Biom dry $_{\text {. }}$ \\
\hline & 31 Jul 2015 & TN5 & Trapa natans & Floating & $45.1608 \mathrm{~N}, 10.7356 \mathrm{E}$ & fC, LAI, Biom ${ }_{\text {dry }}$ \\
\hline
\end{tabular}

$f C^{*}, L A I^{*}$ and $B_{i o m}{ }_{d r y}^{*}$ for submerged species refer to the part of plants reaching the water surface. 
panel with near Lambertian properties). Spectral measurements with excessive environmental noise (values exceeding \pm 2 standard deviation from the mean) due to atmospheric variation or presence of water were excluded from the analysis and the mean reflectance spectra per macrophyte plot was calculated. A variation on this protocol was used to collect data from C. demersum and N. marina stands whereby spectra were collected for the above surface water portion of the plant at height of $20 \mathrm{~cm}$ above the plot; the plot mean was then computed without filtering for noise. During the sampling campaigns, georeferenced photos (coordinates were acquired using GPS; Trimble GeoXM) from nadir position (at approximately $1 \mathrm{~m}$ above canopy) of macrophyte plots were acquired with a compact RGB camera (Sony DSC-HX60).

Macrophyte fractional cover (fC), i.e., the percentage of a horizontal surface occupied by vegetation as seen in nadiral direction, were derived from in situ collected georeferenced photos. During the fieldwork, for each macrophyte plot sampled we took three photos from nadir, approximately $1 \mathrm{~m}$ above the canopy, framing a square plot of $1 \mathrm{~m} \times 1 \mathrm{~m}$. Pixels of each photo were classified based on their RGB values in five different clusters by applying an ISODATA algorithm (Tou and Gonzalez, 1974), and each of five clusters were labelled as vegetation or water. $\mathrm{fC}$ was finally recorded as the average percentage of plot area $\left(1 \mathrm{~m}^{2}\right)$ covered by vegetation over the three photos of each macrophyte sampling site. For submerged species (CD and NM), only the portion of plant canopy reaching the water surface was considered.

Macrophyte leaf area index (LAI, $\mathrm{m}^{2} \mathrm{~m}^{-2}$ ) was derived from the same photos used for fractional cover. For each nadiral image, the areal size of each leaf (considering the overlapping of multiple leaves) falling within the framed square plot was calculated by manual digitization. This method directly returns measures close to the actual LAI for floating and floating-leaved species (e.g., T. natans, $N$. lutea), the leaves of which lie on the water surface, while it underestimates the actual LAI for species with emerging leaves (e.g., N. nucifera). For this species in fact, it is not possible to directly measure from canopy nadiral takes the leaf surface, but only the size of its projection onto the horizontal plane. However, given the slightly concave shape and the almost horizontal arrangement of the circular peltate leaves of $N$. nucifera, the actual LAI underestimation is considered to be limited for the scope of this study. For submerged species (CD and NM), only the portion of plant canopy reaching the water surface was considered, thus resulting in LAI scores which are the same as fractional cover. LAI for each sample was calculated as the mean total leaf area falling within the $1 \mathrm{~m}^{2}$ plot over the three photos of each macrophyte sampling site.

For measuring macrophyte biomass different approaches were used, depending on the macrophyte type.
The number of leaves was counted from photos taken over a $1 \mathrm{~m}^{2}$ plot randomly placed ( 3 replicates) over the floating and emergent macrophytes (NA, NL, and NN) beds. Intact leaves for NA, NL, and NN were collected $(\mathrm{n}=3$ per plot) and brought back to the laboratory for biomass estimation. The number of $T$. natans rosettes was determined from photos taken over a $1.0 \mathrm{~m}^{2}$ plot and intact rosettes were collected, as previously described for floating plants. To measure biomass of submerged and free-floating species (CD and AF, respectively), plants were collected inside a $0.09 \mathrm{~m}^{2}$ and $19.6 \mathrm{~cm}^{2}$ frame, respectively, randomly placed (3 replicates) over the plant beds. For all species, fresh biomass samples were dried in oven at $70^{\circ} \mathrm{C}$ and then weighed on a precision balance. Data presented as areal density of above-water biomass $\left(\right.$ Biom $_{\text {dry }}, \mathrm{kg} \mathrm{m}^{-2}$ ) was obtained by multiplying leaf (NA, $\mathrm{NL}, \mathrm{NN}$ ) or plant (TN) dry weight for the number of leaves or plants per square meter. AF biomass $\left(\mathrm{kg} \mathrm{m}^{-2}\right)$ was obtained dividing the dry weight by the sampling frame area $\left(19.6 \mathrm{~cm}^{2}\right)$ and multiplying by $10,000 \mathrm{~cm}^{2}$ to convert the data to mass per $\mathrm{m}^{2}$. For submerged species, above-water biomass was calculated by assuming that approximately $10 \%$ of total plant biomass is reaching the water surface in peak of growth conditions (such as the ones observed on sampling dates). CD and NM total biomass $\left(\mathrm{kg} \mathrm{m}^{-2}\right)$ was obtained dividing the dry weight by the area $\left(900 \mathrm{~cm}^{2}\right)$ of the sampling frame used, and multiplying by $10,000 \mathrm{~cm}^{2}$ to convert the data to mass per $\mathrm{m}^{2}$. Above-water biomass was finally calculated as $10 \%$ of total biomass sampled. After weighing, selected leaves were ground to a powder and analysed according to Aspila et al. (1976) for determining total phosphorus (P) content.

In addition to morphological trait data, in the Mantua lakes system we recorded georeferenced field observations of the presence of L. hexapetala and Lemna spp.

\section{Airborne hyperspectral data}

Airborne hyperspectral data were acquired from the Airborne Prism Experiment (APEX) imager (Schaepman et al., 2015). APEX images were acquired on 19 July 2014 over Lake Hídvégi (three flight lines, 11:50-12:10 local time, orientation $\sim 30^{\circ}$ azimuth) and on 27 September 2014 over the Mantua lakes system (five flight lines, 13:3014:00 local time, orientation $\sim 50^{\circ}$ azimuth), with ground spatial resolution of $5 \mathrm{~m}$. Additional APEX data acquired over Mantua lakes system on 21 September 2011 (five flight lines, 16:00-16:30 local time, orientation $\sim 50^{\circ}$ azimuth) were used for comparison with 2014 data.

The APEX data were radiometrically calibrated by the APEX Calibration Home Base (CHB) hosted at DLR Oberpfaffenhofen, Germany (Gege et al., 2009), and georeferenced based on sensor's GPS/IMU, including boresight correction. The atmospheric correction of the data was performed by with the MODTRAN4 radiative transfer code 
following the algorithms optimized for water targets (De Haan et al., 1991) and taking into account smile effects. For the atmospheric parameters, in situ sunphotometer observations (Microtops II on Lake Hídvégi, EKO MS-120 on the Mantua lakes system) simultaneous with APEX acquisitions were used. The reflectance spectra were smoothed using EOSap_Smoothing IDL routine (https://sourceforge.net/p/ enviidlcodelibr/wiki/EOSap_Smoothing/).

Only the visible and near-infrared bands (426-906 $\mathrm{nm}$ ) were retained for further processing, resulting in a data cube of 98 spectral bands with 3-10 nm spectral resolution.

\section{Estimation of macrophyte morphological traits}

Macrophyte canopy morphological traits (MTs): fractional cover (fC), leaf area index (LAI) and above-water biomass $\left(\right.$ Biom $\left._{\text {dry }}\right)$ were estimated from spectral data through semi-empirical regression modelling based on spectral vegetation indices. A range of 27 spectral indices focusing on the visible to near infrared spectral range (420-800 nm), developed and documented in scientific literature (related references for each index are cited in Tab. 2) as sensitive to vegetation density and morphology, was tested in order to identify those with potential for retrieval of information on macrophyte morphological traits investigated.

High resolution macrophyte canopy reflectance data collected in situ were spectrally resampled to match APEX visible and near-infrared bands (in the range 420$800 \mathrm{~nm}$ ), and then used to derive the narrowband SIs listed in Tab. 2, corresponding to each plot sampled during fieldwork. The Pearson (r) correlation coefficient between morphological trait scores and calculated SIs was used as indicator of goodness of fit to inform the selection of the five best SIs for estimating macrophyte fC, LAI and Bio$\mathrm{m}_{\mathrm{dry}}$ through linear regression models (i.e., the SIs scoring highest $r$ values for each morphological trait). For each parameter, linear regression models were then fitted using the five best performing SIs from resampled in situ canopy spectra. The resulting models were also tested by using as input the spectral reflectance data derived directly from APEX pixels corresponding to macrophyte plots sampled within some days from the APEX flights (3-4 days, 14 plots). The APEX spectra were extracted from a $3 \times 3$ windows centred around the location of each sampled plot on georeferenced images, following a maximum vegetated pixel approach. The approach consists in selecting among the 9 pixels the one with highest vegetation coverage, i.e., the pixel with highest reflectance in the NIR range $(780 \mathrm{~nm})$, and retaining the corresponding full reflectance spectra to be compared with macrophyte morphological traits measured. This approach allows to partially correct for the fact that in situ sampling can be frequently biased towards higher vegetation density patches, even within a relatively homogeneous area, and was therefore preferred to taking the mean reflectance over $3 \times 3$ window.

Model errors were assessed in terms of Mean Absolute Error (MAE) and relative Root Mean Square Error (rRMSE):

$$
\begin{aligned}
& \operatorname{MAE}=\frac{1}{N} \sum_{i=1}^{N}\left|f_{i}-y_{i}\right| \\
& \text { rRMSE }=\frac{\sqrt{\frac{\sum_{i=i}^{N}\left(f_{i}-y_{i}\right)^{2}}{N}}}{\sum_{i=i}^{N} y_{i}}
\end{aligned}
$$

where $f_{i}$ is the estimated parameter, $y_{i}$ the parameter measured in situ, $\mathrm{N}$ the number of observations. Among the linear regression models calculated from five best in situ SIs, for each morphological trait we finally selected the linear model which scored lower estimation error (MAE and rRMSE) when using APEX pixel spectra. The three retained models were applied to the entire APEX image cubes for producing maps of macrophyte fC, LAI, and Biom $_{\text {dry }}$ of Mantua lakes system and Lake Hídvégi areas at the time of APEX data acquisition.

Regression line slope, P-value ( $F$-test), and correlation coefficient (Pearson's r) between MT measured in situ and estimated with best performing semi-empirical linear model applied to APEX data were calculated in order to assess and quantify the macrophyte morphological trait mapping performance over the two study areas.

\section{RESULTS}

\section{Morphological traits modelling using spectral indices}

For each macrophyte morphological trait investigated, the best performing spectral proxy was selected among the SIs tested (Tab. 2). Tab. 3 summarizes the results of SIs performance assessment using reflectance spectra derived from the in situ and APEX data respectively. The error level of atmospherically corrected APEX data was quantified as lower than 5\% reflectance over macrophyte canopy across the 420-800 nm spectral range (see Supplementary Fig. 1 for details), with some deviations outside the $5 \%$ error margin only for some samples (i.e., N. lutea in Lake Hídvégi, and $N$. nucifera in Mantua lakes system).

Macrophyte canopy fractional cover (fC) was estimated with high consistency $(r>0.84)$ and low error (MAE $<6.6 \%$ ) using four different background adjusted SIs with VIS-NIR bands (GSAVI, SAVI, EVI, and WAVI), as well as using RDVI. GSAVI scored the highest correlation $(\mathrm{r}=0.88)$ and lowest estimation error (MAE $=5.4 \%$, rRMSE $=0.10$, using APEX spectra) among 
these indices, and was selected for estimating $\mathrm{fC}$ through linear regression, using equation 3 :

$\mathrm{fC}(\%)=105.0(\mathrm{GSAVI})+23.3$
Similarly to fC, macrophyte canopy LAI was consistently $(\mathrm{r}>0.87)$ and accurately $\left(\mathrm{MAE}<0.16 \mathrm{~m}^{2} \mathrm{~m}^{-2}\right)$ estimated by three background enhanced VIS-NIR SIs (EVI, GSAVI and WAVI), and by RDVI. Comparable performance was achieved with $\mathrm{MCARI}_{705}$, which includes spec-

Tab. 2. Spectral indices sensitive to vegetation features tested in the study.

\begin{tabular}{|c|c|c|c|c|}
\hline Name & Acronym & Formula & Spectral range, type & Reference \\
\hline Canopy Chlorophyll Content Index & $\mathrm{CCCI}$ & $\frac{\frac{\rho 780-\rho 710}{\rho 780+\rho 710}}{\frac{\rho 780-\rho 670}{\rho 780+\rho 670}}$ & RE-NIR & Barnes et al., 2000 \\
\hline Chlorophyll Green & $\mathrm{Chl}_{\text {green }}$ & $\frac{\rho 550}{\rho 780}$ & VIS-NIR & Gitelson et al., 2006 \\
\hline Chlorophyll Index Green & $\mathrm{CI}_{\text {green }}$ & $\frac{\rho 780}{\rho 550}-1$ & VIS-NIR & Hunt et al., 2011 \\
\hline Chlorophyll Index RedEdge & CIre & $\frac{\rho 780}{\rho 710}-1$ & RE-NIR & Hunt et al., 2011 \\
\hline Chlorophyll Index RedEdge 750 & CIre $_{750}$ & $\frac{\rho 750}{\rho 710}-1$ & RE-NIR & Wu et al., 2009 \\
\hline Chlorophyll vegetation index & CVI & $\rho 780 \frac{\rho 670}{\rho 550^{2}}$ & VIS-NIR & Hunt et al., 2011 \\
\hline Enhanced Vegetation Index & EVI & $2 \frac{\rho 780-\rho 670}{\rho 780+6 \rho 670-7.5 \rho 470+1}$ & $\begin{array}{l}\text { VIS-NIR, } \\
\text { background adjusted }\end{array}$ & Huete et al., 2002 \\
\hline Green Leaf Index & GLI & $\frac{2 \rho 550-\rho 670-\rho 550}{2 \rho 550+\rho 670+\rho 550}$ & VIS & Gobron et al., 2000 \\
\hline $\begin{array}{l}\text { Green Normalized Difference } \\
\text { Vegetation Index }\end{array}$ & GNDVI & $\frac{\rho 780-\rho 550}{\rho 780+\rho 550}$ & VIS-NIR & $\begin{array}{l}\text { Gitelson and Merzlyak, } \\
1994\end{array}$ \\
\hline Green Soil Adjusted Vegetation Index & GSAVI & $1.5 \frac{\rho 780-\rho 550}{\rho 780+\rho 550+0.5}$ & $\begin{array}{l}\text { VIS-NIR, } \\
\text { background adjusted }\end{array}$ & Tian et al., 2005 \\
\hline Maccioni & Maccioni & $\frac{\rho 780-\rho 710}{\rho 780+\rho 680}$ & VIS-RE-NIR & Maccioni et al., 2001 \\
\hline $\begin{array}{l}\text { Modified Chlorophyll Absorption } \\
\text { in Reflectance Index }\end{array}$ & MCARI & {$[(\rho 700-\rho 670)-0.2(\rho 700-\rho 550)] \frac{\rho 700}{\rho 670}$} & VIS-RE & Haboudane et al., 2004 \\
\hline $\begin{array}{l}\text { Modified Chlorophyll Absorption } \\
\text { in Reflectance Index } 1\end{array}$ & MCARI1 & $1.2[2.5(\rho 800-\rho 670)-1.3(\rho 800-\rho 550)]$ & $\begin{array}{l}\text { VIS-NIR, } \\
\text { background adjusted }\end{array}$ & Haboudane et al., 2004 \\
\hline $\begin{array}{l}\text { Modified Chlorophyll Absorption } \\
\text { in Reflectance Index } 2\end{array}$ & MCARI2 & $1.5 \frac{2.5(\rho 800-\rho 670)-1.3(\rho 800-\rho 550)}{\sqrt{(2 \rho 800+1)^{2}-6 \rho 800+5 \sqrt{\rho 670}-0.5}}$ & $\begin{array}{l}\text { VIS-NIR, } \\
\text { background adjusted }\end{array}$ & Haboudane et al., 2004 \\
\hline $\begin{array}{l}\text { Modified Chlorophyll Absorption } \\
\text { in Reflectance Index 705,750 }\end{array}$ & $\mathrm{MCARI}_{705}$ & {$[(\rho 750-\rho 705)-0.2(\rho 750-\rho 550)] \frac{\rho 750}{\rho 705}$} & VIS-RE-NIR & Wu et al., 2009 \\
\hline MERIS Terrestrial Chlorophyll Index & MTCI & $\frac{\rho 754-\rho 709}{\rho 709+\rho 681}$ & VIS-RE-NIR & Dash and Curran, 2004 \\
\hline Modified Triangular Vegetation Index 1 & MTVI1 & $1.2(\rho 800-\rho 550)-2.5(\rho 670-\rho 550)$ & VIS-NIR & Haboudane et al., 2004 \\
\hline Modified Triangular Vegetation Index 2 & MTVI2 & $1.5 \frac{1.2(\rho 800-\rho 550)-2.5(\rho 670-\rho 550)}{\sqrt{(2 \rho 800+1)^{2}-6 \rho 800+5 \sqrt{\rho 670}-0.5}}$ & $\begin{array}{l}\text { VIS-NIR, } \\
\text { background adjusted }\end{array}$ & Haboudane et al., 2004 \\
\hline $\begin{array}{l}\text { Normalized Difference Aquatic } \\
\text { Vegetation Index }\end{array}$ & NDAVI & $\frac{\rho 780-\rho 470}{\rho 780+\rho 470}$ & VIS-NIR & Villa et al., 2014 \\
\hline Normalized Difference RedEdge Index & NDRE & $\frac{\rho 780-\rho 710}{\rho 780+\rho 710}$ & RE-NIR & Barnes et al., 2000 \\
\hline Normalized Difference Vegetation Index & NDVI & $\frac{\rho 780-\rho 670}{\rho 780+\rho 670}$ & VIS-NIR & Rouse et al., 1974 \\
\hline Renormalized Difference Vegetation Index & RDVI & $\frac{\rho 800-\rho 670}{\sqrt{\rho 800+\rho 670}}$ & VIS-NIR & Chen, 1996 \\
\hline Soil Adjusted Vegetation Index & SAVI & $1.5 \frac{\rho 780-\rho 670}{\rho 780+\rho 670+0.5}$ & $\begin{array}{l}\text { VIS-NIR, } \\
\text { background adjusted }\end{array}$ & Huete, 1988 \\
\hline Simple Ratio & SR & $\frac{\rho 780}{\rho 670}$ & VIS-NIR & Tucker et al, 1979 \\
\hline $\begin{array}{l}\text { Transformed Normalized Difference } \\
\text { Vegetation Index }\end{array}$ & TNDVI & $\sqrt{\frac{\rho 780-\rho 670}{\rho 780+\rho 670}+0.5}$ & VIS-NIR & Bannari et al., 1995 \\
\hline Triangular Vegetation Index & TVI & $0.5[120(\rho 750-\rho 550)-200(\rho 670-\rho 550)]$ & VIS-NIR & Broge and Leblanc, 2001 \\
\hline Water Adjusted Vegetation Index & WAVI & $1.5 \frac{\rho 780-\rho 470}{\rho 780+\rho 470+0.5}$ & $\begin{array}{l}\text { VIS-NIR, } \\
\text { background adjusted }\end{array}$ & Villa et al., 2014 \\
\hline
\end{tabular}


tral information in the red edge range (around $705 \mathrm{~nm}$ ). Highest correlation $(\mathrm{r}=0.91)$ and lowest error $(\mathrm{MAE}=0.10$ $\mathrm{m}^{2} \mathrm{~m}^{-2}, \mathrm{rRMSE}=0.18$, using APEX spectra) were scored by EVI, which was selected for estimating LAI using the linear regression, using equation 4 :

LAI $\left(\mathrm{m}^{2} \mathrm{~m}^{-2}\right)=1.566(\mathrm{EVI})+0.057$

Range: [0.0-1.8 $\mathrm{m}^{2} \mathrm{~m}^{-2}$ ]

(eq. 4)

Above-water biomass $\left(\right.$ Biom $\left._{\mathrm{dry}}\right)$ was found to be better correlated with SIs that include spectral bands centred in the red edge range (around 705-710 nm), and the five best performing indices for this parameter were MTCI, $\mathrm{CIre}_{750}$, $\mathrm{MCARI}_{705}$, CIre, and Maccioni ( $\mathrm{r}>0.82$, MAE $0.08 \mathrm{~kg} \mathrm{~m}^{-}$ ${ }^{2}$ ). All these SIs showed a strong saturation effect with increasing biomass and a severe loss of sensitivity for Biom ${ }_{\mathrm{dry}}$ values higher than $0.5 \mathrm{~kg} \mathrm{~m}^{-2}$. For this reason, the semi-empirical linear model for estimating Biom $_{\text {dry }}$ was calibrated using samples with biomass measured in situ not exceeding this threshold, i.e., excluding two T. natans samples collected in Mantua lakes system site during 2015. Among the best SIs, CIre scored the highest correlation $(\mathrm{r}=0.83)$ and lowest estimation error using APEX spectra (MAE $=0.06 \mathrm{~kg}$ $\mathrm{m}^{-2}, \mathrm{rRMSE}=0.42$ ), and was selected for estimating abovewater biomass by linear regression, using equation 5 :

$\operatorname{Biom}_{\text {dry }}\left(\mathrm{kg} \mathrm{m}^{-2}\right)=0.147($ CIre $)-0.007$

(eq. 5)

Range: [0.0-0.5 $\left.\mathrm{kg} \mathrm{m}^{-2}\right]$

\section{Macrophyte morphological trait maps}

Maps of canopy morphological traits were produced by applying the semi-empirical models described by equation 3 (fC), equation 4 (LAI) and equation $5\left(\right.$ Biom $\left._{\mathrm{dry}}\right)$ to APEX images: on 19 July 2014 for Lake Hídvégi site, and on 27 September 2014 and 21 September 2011 for Mantua lakes system. For both study sites, morphological traits maps were produced only for the areas covered by floating and emergent macrophytes, which are isolated from other vegetation and different land cover types by using a binary raster mask produced by thresholding aquatic vegetation index scores (WAVI $>0$ ) for APEX image pixels falling within the water body area delineated by official cartography.

Figs. 2 and 3, respectively, show the macrophyte fractional cover map of Lake Hídvégi (19 July 2014) and macrophyte above-water biomass of Mantua lakes system (27 September 2014) produced by applying the calibrated models to APEX data. Selected macrophyte beds (12 for Lake Hídvégi, 18 for Mantua) are delineated and highlighted in yellow over Figs. 2 and 3, comprising those surveyed during 2014 field campaigns ( 8 for Lake Hídvégi, 9 for Mantua) and some additional stands covered by the most relevant plant species present.

Macrophyte morphological traits mapping performance (Fig. 4) using APEX data was tested with respect to in situ measurements taken near contemporaneously (within 4 days) to the flights over both study sites $(\mathrm{n}=14)$.

Tab. 3. Selection of best performing linear semi-empirical regression model macrophyte morphological traits using spectral reflectance data (best performing Spectral Index for each parameter using APEX data as input is highlighted in bold).

\begin{tabular}{|c|c|c|c|c|c|c|c|}
\hline \multirow[b]{2}{*}{ Morphological trait } & \multirow[b]{2}{*}{ SI } & \multicolumn{3}{|c|}{$\begin{array}{l}\text { Calibration (in situ) } \\
\qquad \begin{array}{c}n=26(\mathrm{fC}, \mathrm{LAI}) \\
n=24\left(\text { Biom }_{\mathrm{dry}}\right)\end{array}\end{array}$} & \multicolumn{3}{|c|}{$\begin{array}{c}\text { Testing (APEX) } \\
n=14\end{array}$} \\
\hline & & $\mathbf{r}$ & MAE & rRMSE & $\mathbf{r}$ & MAE & rRMSE \\
\hline \multirow[t]{5}{*}{$\mathrm{fC}(\%)$} & GSAVI & 0.879 & $5.7 \%$ & 0.09 & 0.938 & $5.4 \%$ & 0.10 \\
\hline & SAVI & 0.861 & $6.3 \%$ & 0.10 & 0.925 & $6.1 \%$ & 0.11 \\
\hline & RDVI & 0.858 & $6.5 \%$ & 0.10 & 0.932 & $7.0 \%$ & 0.12 \\
\hline & EVI & 0.852 & $6.2 \%$ & 0.11 & 0.902 & $5.6 \%$ & 0.10 \\
\hline & WAVI & 0.845 & $6.6 \%$ & 0.11 & 0.922 & $6.6 \%$ & 0.12 \\
\hline \multirow[t]{5}{*}{$\operatorname{LAI}\left(\mathrm{m}^{2} \mathrm{~m}^{-2}\right)$} & EVI & 0.912 & 0.10 & 0.13 & 0.895 & 0.10 & 0.18 \\
\hline & RDVI & 0.907 & 0.11 & 0.14 & 0.919 & 0.16 & 0.25 \\
\hline & GSAVI & 0.905 & 0.12 & 0.15 & 0.915 & 0.14 & 0.23 \\
\hline & $\mathrm{MCARI}_{705}$ & 0.901 & 0.12 & 0.15 & 0.952 & 0.14 & 0.23 \\
\hline & WAVI & 0.868 & 0.13 & 0.17 & 0.879 & 0.16 & 0.28 \\
\hline \multirow[t]{5}{*}{$\operatorname{Biom}_{\text {dry }}\left(\mathrm{kg} \mathrm{m}^{-2}\right)$} & MTCI & 0.868 & 0.04 & 0.26 & 0.790 & 0.08 & 0.53 \\
\hline & $\mathrm{CIre}_{750}$ & 0.836 & 0.04 & 0.29 & 0.777 & 0.07 & 0.44 \\
\hline & MCARI $_{705}$ & 0.830 & 0.05 & 0.32 & 0.780 & 0.07 & 0.49 \\
\hline & CIre & 0.827 & 0.05 & 0.29 & 0.777 & 0.06 & 0.42 \\
\hline & Maccioni & 0.817 & 0.04 & 0.29 & 0.797 & 0.07 & 0.47 \\
\hline
\end{tabular}


Results showed the good reliability of $\mathrm{fC}(\mathrm{r}=0.94)$ between estimated and measured scores (Fig. 4a) and LAI $(\mathrm{r}=0.88)$ maps, although a tendency towards underestimation for high LAI values ( $N$. nucifera sample plot) was observed (Fig. 4b). Biomass estimates (Fig. 4c) showed acceptable results ( $\mathrm{r}=0.55$ between estimated and measured scores), but were again biased towards underestimation (regression slope $=0.72$ ). All morphological traits estimated were statistically significant with P-value ( Ftest) lower than 0.0011 .

\section{Spatial and species-dependant variability}

Morphological trait statistical descriptors were extracted in correspondence of selected macrophyte beds (highlighted in Figs. 2 and 3) from Lake Hídvégi and Mantua lakes system maps derived from APEX data for 2014. From these beds, an overall representation of both spatial and species-dependant variability can be derived for the main aquatic plant communities in our study sites. Fig. 5 shows the box plots $(5,25,50,75$, and 95 percentile) of fractional cover, LAI and above-water biomass for all selected beds (Figs. 2 and 3).

For Lake Hídvégi, the 12 macrophyte stands are divided into two groups, composed by submerged and floatingleaved species. Taking into account only the plant parts reaching the water surface, MTs of submerged plants $(\mathrm{CD}$ and $\mathrm{NM}$ ) showed mean values ( $\mathrm{fC}<30 \%$, $\mathrm{LAI}<0.19 \mathrm{~m}^{2}$ $\mathrm{m}^{-2}$ and $\mathrm{Biom}_{\mathrm{dry}}<0.06 \mathrm{~kg} \mathrm{~m}^{-2}$ ) lower than those derived for floating-leaved species (Fig. 5 a,c,e). Among all T. natans

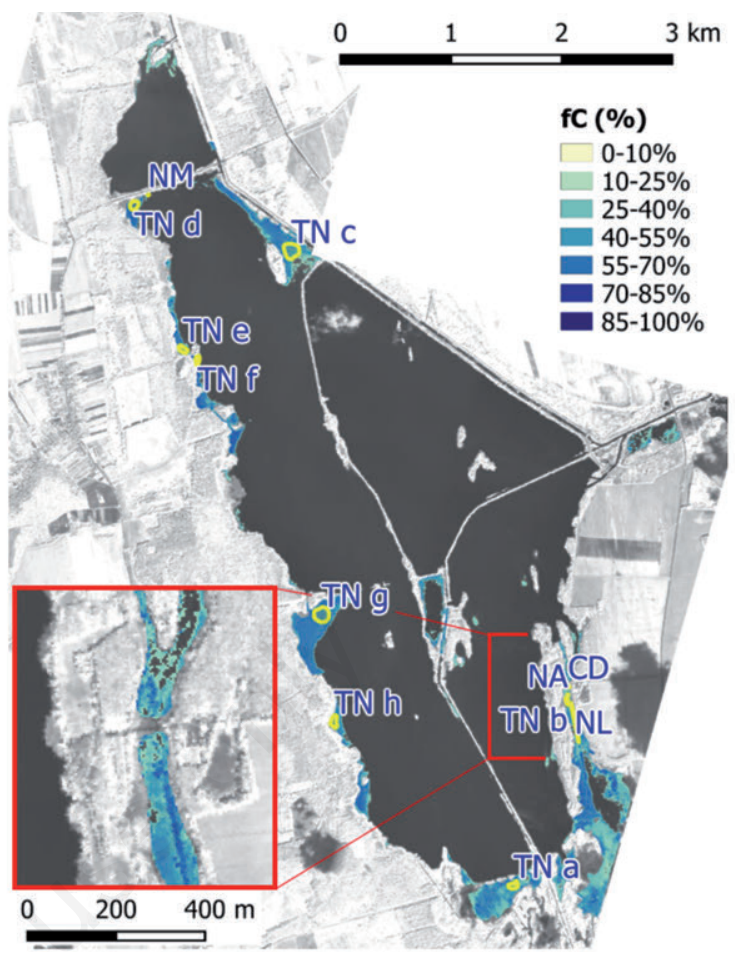

Fig. 2. Map of macrophyte fractional cover for Lake Hídvégi (19 July 2014) derived from APEX data. A discrete color legend is used for visualization of the continuous value fC map. Macrophyte beds over which the discussion focused are highlighted in the figure with their identifier (yellow layers). CD, Ceratophyllum demersum; NM, Najas marina; TN, Trapa natans; NA, Nymphaea alba; NL, Nuphar lutea.

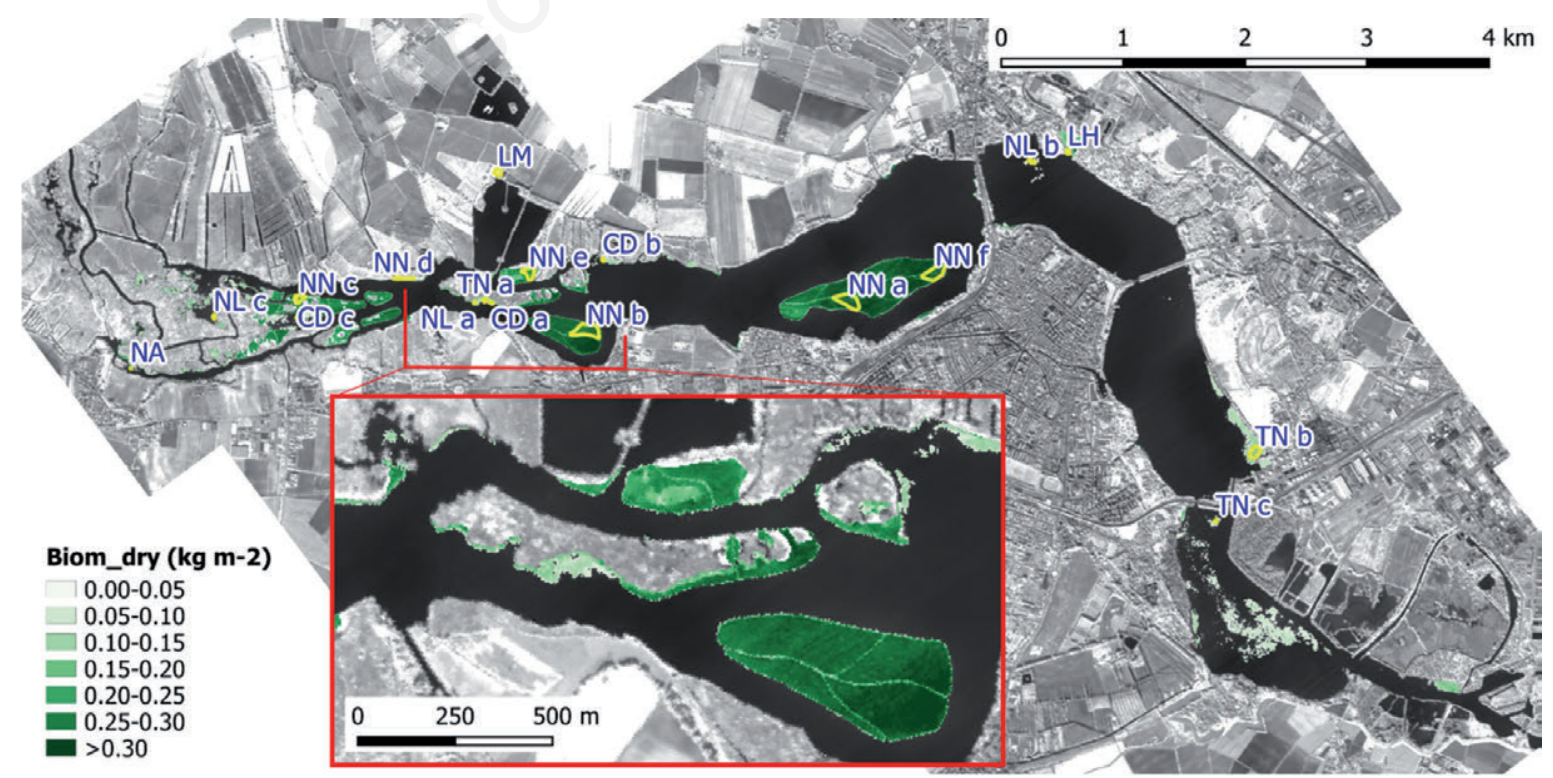

Fig. 3. Map of macrophyte above-water biomass for Mantua lakes system (27 September 2014) derived from APEX data. A discrete color legend is used for visualization of the continuous value Biomdry map. Macrophyte beds over which the discussion focused are highlighted in the figure with their identifier (yellow layers). CD, Ceratophyllum demersum; TN, Trapa natans; NA, Nymphaea alba; NL, Nuphar lutea; NN, Nelumbo nucifera; LM, Lemna spp.; LH, Ludwigia hexapetala. 
beds, $\mathrm{TNb}$ stand, located within a narrow water channel in the eastern portion of Basin 3 (Fig. 1) in the Lake Hídvégi (water depth 0.9-1.1 m under macrophyte beds), had significantly lower MTs mean values ( $\mathrm{fC}=49 \%, \mathrm{LAI}=0.57 \mathrm{~m}^{2}$ $\mathrm{m}^{-2}$ and Biom $_{\mathrm{dry}}=0.11 \mathrm{~kg} \mathrm{~m}^{-2}$ ). TNb morphological traits were statistically different (non-parametric Dunn's test, 99\% confidence level) from any other $\mathrm{TN}$ beds ( $\mathrm{fC}=68 \pm 4 \%$, $\mathrm{LAI}=0.89 \pm 0.08 \mathrm{~m}^{2} \mathrm{~m}^{-2}$, and $\left.\mathrm{Biom}_{\text {dry }}=0.15 \pm 0.02 \mathrm{~kg} \mathrm{~m}^{-2}\right)$. Instead, T. natans beds were located in Basin 2 (water depth $0.50-0.65 \mathrm{~m}$ under macrophyte beds) and in particular TNd$\mathrm{h}$ were along the western side of this sub-basin showed similar traits (see Fig. 2). NA and NL beds located in the Basin 3 presented MTs mean values similar to that reported for TNd-h beds (Fig. 5 a,c,e).

From the plots of the Mantua lakes system (Fig. 5 $\mathrm{b}, \mathrm{d}, \mathrm{f})$, the 18 macrophyte stands can be grouped into four groups: i) submerged (CDa-c); ii) free-floating and floating-leaved (LM, TNa-c, NA, NLa-c); iii) emergent rhizophyte (NNa-f); and iv) floating mat-forming ( $\mathrm{LH}$ ) plants. In September 2014, A. filiculoides was not present in the Mantua lakes system due to weather conditions (high precipitation and water discharge) that were unfavourable to plant establishment and persistence and therefore we will not discuss this macrophyte functional group. All MTs values followed a gradient: submerged $<$ floating $<$ emergent/mat-forming (Fig. 5 b,d,f). The high vigour and areal cover of the $N$. nucifera beds, due to the presence of floating-leaved and emergent leaves, were reflected in the highest MTs values (LAI $=1.21-1.36 \mathrm{~m}^{2} \mathrm{~m}^{-2}$; Bio$\mathrm{m}_{\mathrm{dry}}=0.23-0.29 \mathrm{~kg} \mathrm{~m}^{-2}$ ), found also for the other invasive species (i.e., L. hexapetala). Similarly to floating-leaved species for which fractional cover is the portion of water covered by leaves, for submersed forms the $\mathrm{fC}$ is the portion of the plant which reaches the water surface layer. Therefore, it is expected that CD beds showed the lowest fC mean values (18-20\%) and NN beds the highest (85-
93\%) (Fig. 5b). LM and TNb showed the second highest LAI values $\left(0.91\right.$ and $0.87 \mathrm{~m}^{2} \mathrm{~m}^{-2}$, respectively) after NNa-f and LH beds (Fig. 5d). TNa, TNb, and TNc beds were located in the Superior Lake, Inferior Lake and Vallazza wetland, respectively. T. natans bed in the Inferior Lake $(\mathrm{TNb})$ showed higher fC and LAI values $(70 \%$ and $0.87 \mathrm{~m}^{2} \mathrm{~m}^{-2}$, respectively) compared to the other two beds (45-46\%, and 0.41-0.45 $\mathrm{m}^{2} \mathrm{~m}^{-2}$, respectively, Fig. $5 \mathrm{~b}-\mathrm{d}$ ), probably due to a different phenological status, which was not reflected so clearly by biomass values (Fig. 5f). In fact, in 2014 T. natans in the Inferior Lake emerged twothree months later than the other T. natans beds, which therefore already reached a more advanced maturation stage in late September. N. lutea stands showed that MTs mean values were lower in the Middle Lake (NLb; $\mathrm{fC}=41 \% ; \mathrm{LAI}=0.39 \mathrm{~m}^{2} \mathrm{~m}^{-2} ;$ Biom $_{\text {dry }}=0.06 \mathrm{~kg} \mathrm{~m}^{-2}$ ) compared to the other $N$. lutea stands growth in the Superior Lake (NLa, c), as seen in Fig. 5 b,d,f.

\section{Temporal variability}

For the Mantua lakes system, we compared MTs maps derived from APEX data of 27 September 2014 with homologous maps derived from APEX data collected on 21 September 2011. Although the September 2011 maps cannot be validated due to the absence of in situ data on macrophyte MTs, a qualitative comparison can be carried out if we assume radiometric consistency and similar atmospheric and geometric acquisition conditions for both APEX flights. An assessment of APEX reflectance spectra matching carried out over targets considered to be radiometrically stable throughout the three years from 2011 to 2014 showed that the relative difference between the two images is under $4 \%$, that is lower than radiometric accuracy of 2014 data $v$ s in situ spectra (see Supplementary Fig. 2 for details).
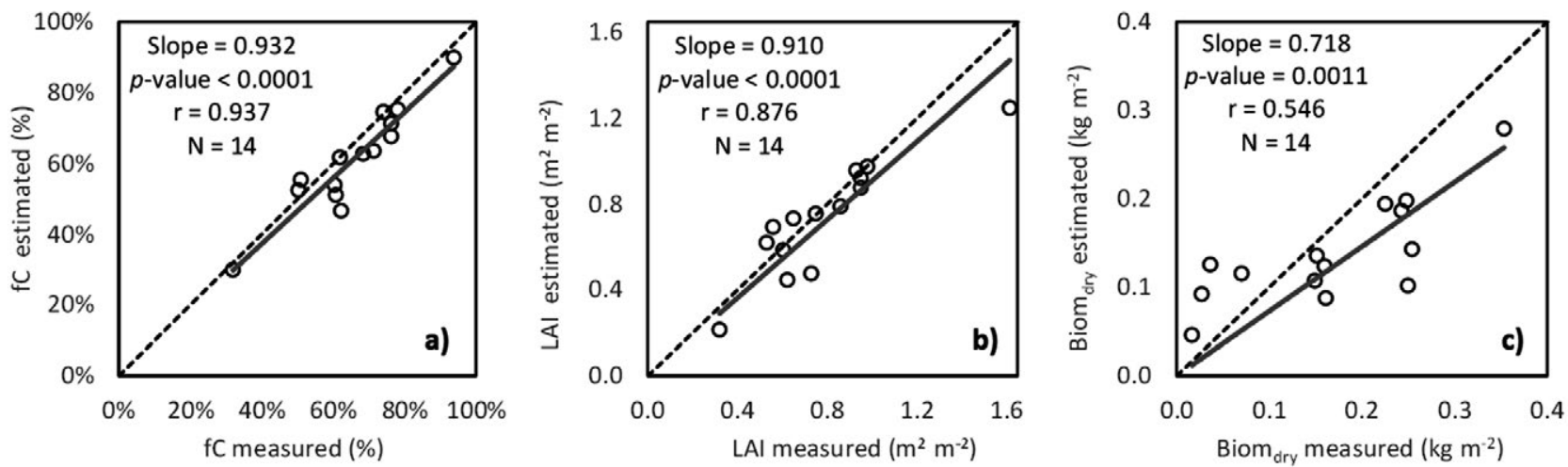

Fig. 4. Comparison of macrophyte canopy morphological traits measured in situ with estimates derived from spectral reflectance data using best performing linear model applied to APEX data. a) fC. b) LAI. c) Biom dry. Regression line slope, P-value, Pearson's r, and number of samples $(\mathrm{N})$ are superimposed on each graph. 
In order to evaluate the difference between the products obtained by APEX 2011 and 2014, we have collected meteorological data of the vegetative period (March-October) of these two years. Meteorological data for both 2011 and 2014 growing seasons were reported in Fig. 6. The amount of precipitation from April to September was comparable between 2011 and 2014 (340 mm and 348 $\mathrm{mm}$, respectively; data source Lombardy Environment Protection Regional Agency), but the seasonal distribution of rainfall varied between years, with a dry spring and rainy start to the summer in 2011 and a wet May followed by dry summer until August when rain was quite abundant in 2014 (Fig. 6a). Air temperature (daily mean) was higher in 2011 compared to 2014 , reflecting the heat wave that hit the north of Italy between middle of August to the end of September 2011 (Fig. 6a). Wind velocity was similar between the two years, except from mid-July to mid-August when higher values were measured in 2011 (Fig. 6b). Solar radiation seasonality resembled that of wind velocity, higher from July to middle of August 2011 than what observed in the summer of 2014 (Fig. 6b).

As observed in 2014, the macrophyte MTs maps derived from 21 September 2011 APEX data consistently show a gradient in the canopy density, decreasing from invasive species to floating-leaved native ones $(\mathrm{NN}>\mathrm{LH}$ $>$ TN+NL; Fig. 8). fC and LAI of N. nucifera in 2011 were comparable between Angeli and Belfiore islands (see islands delineation in Fig. 7) in both years, but lower than in 2014 in absolute values (fC, $\sim 85 \%$ and $~ 91 \%$; LAI, $\sim 1.18$ and $\sim 1.32 \mathrm{~m}^{2} \mathrm{~m}^{-2}$, respectively). L. hexapetala
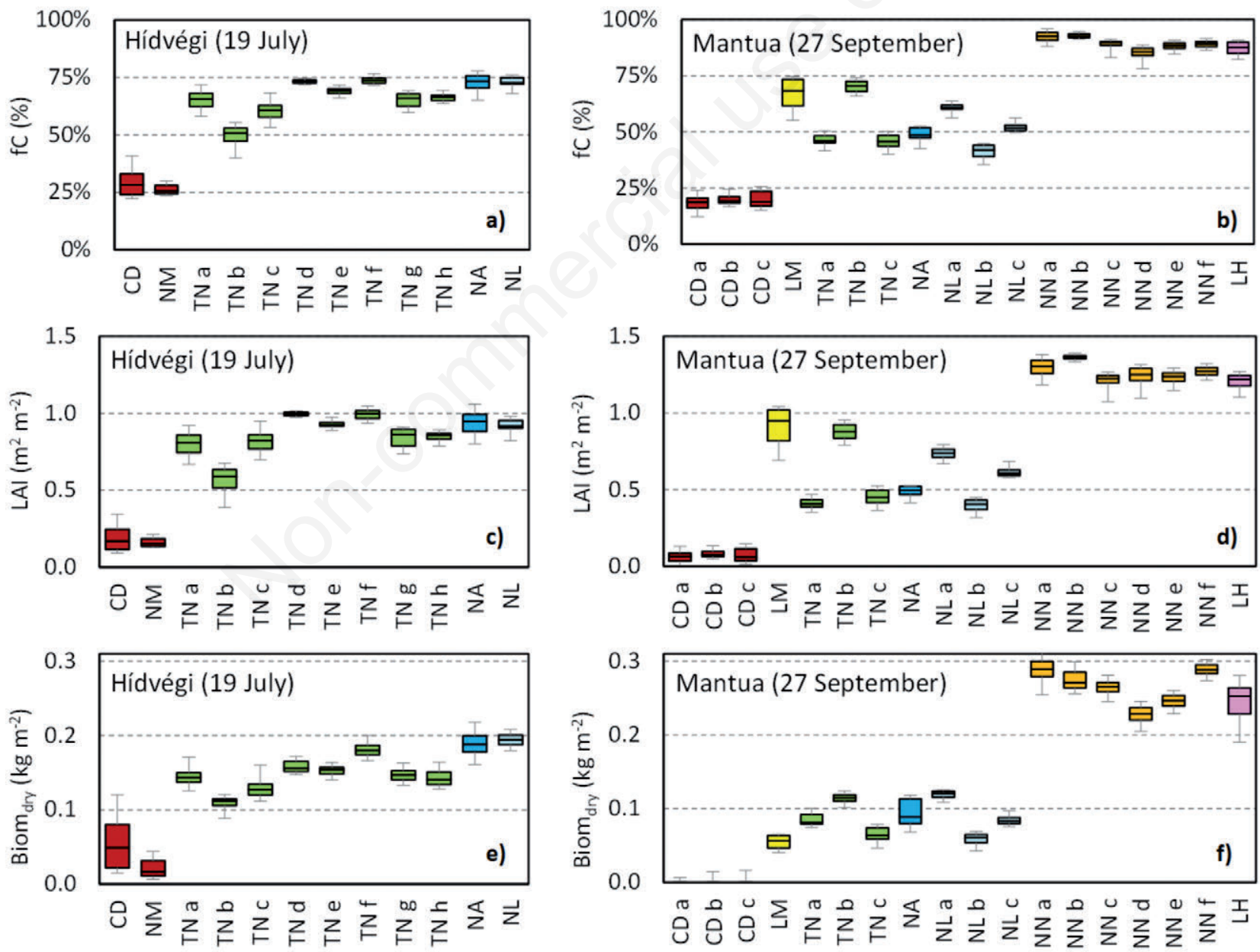

Fig. 5. Box plots (5-25-50-75-95 percentiles) of morphological traits extracted from APEX derived maps for relevant macrophyte beds (see Figs. 2 and 3). a) Fractional cover (Lake Hídvégi, 19 July 2014). b) Fractional cover (Mantua lakes system, 27 September 2014). c) LAI (Lake Hídvégi, 19 July 2014). d) LAI (Mantua lakes system, 27 September 2014). e) Biomass (Lake Hídvégi, 19 July 2014). f) Biomass (Mantua lakes system, 27 September 2014). fC, LAI and Biomdry of submerged species refer to the plant parts reaching the water surface only. CD, Ceratophyllum demersum; NM, Najas marina; TN, Trapa natans; NA, Nymphaea alba; NL, Nuphar lutea; NN, Nelumbo nucifera; LM, Lemna spp.; LH, Ludwigia hexapetala. 
showed fC values similar in both years, while LAI values were higher in 2014 compared to $2011\left(0.94\right.$ and $0.88 \mathrm{~m}^{2}$ $\mathrm{m}^{-2}$, respectively) (Figs. 7 and $8 \mathrm{~b}$ ). Instead, slightly lower LH biomass values were measured in $2014(0.13 \pm 0.05 \mathrm{~kg}$ $\left.\mathrm{m}^{-2}\right)$, than in $2011\left(0.16 \pm 0.05 \mathrm{~kg} \mathrm{~m}^{-2}\right)$. T. natans showed a slight increase in biomass from 2011 to $2014(0.04 \pm 0.02$ and $0.07 \pm 0.03 \mathrm{~kg} \mathrm{~m}^{-2}$, respectively), while fC and LAI were similar in both years (Fig. 8a-b). fC and LAI of $N$.
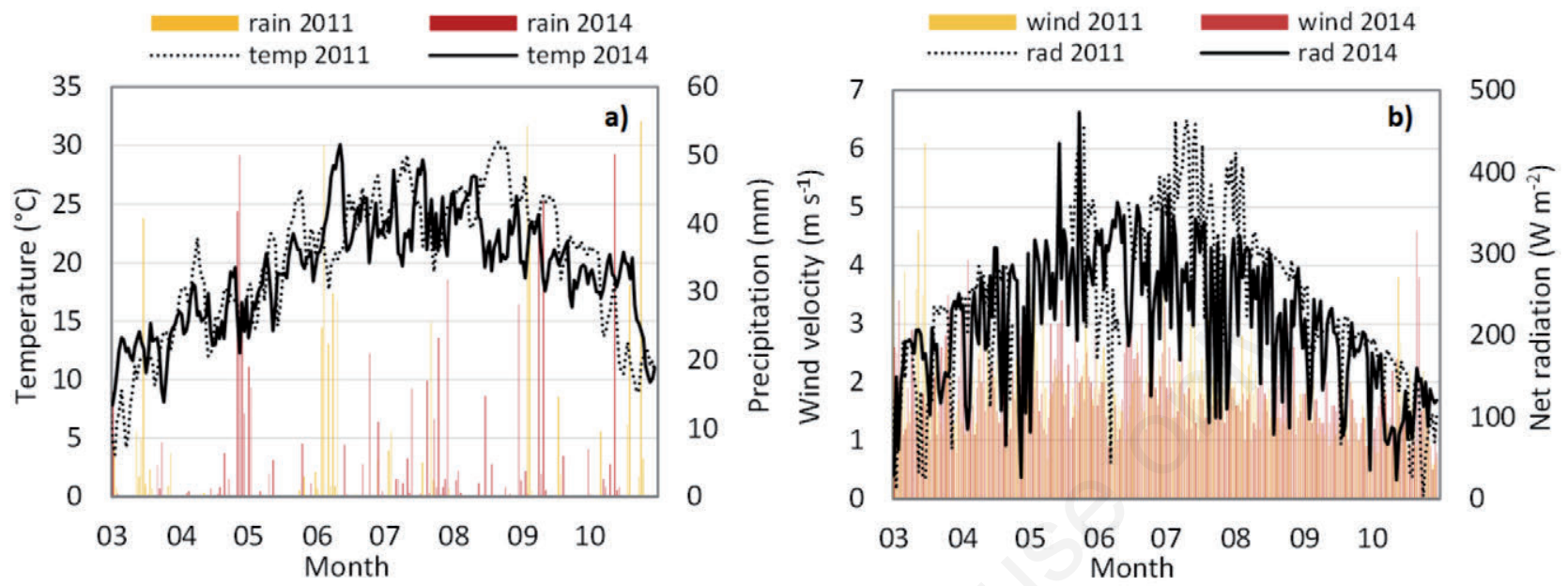

Fig. 6. Meteorological data for Mantua lakes system from March to October in 2011 and 2014. a) Daily mean air temperature and cumulated precipitation. b) Daily mean wind velocity and net radiation.

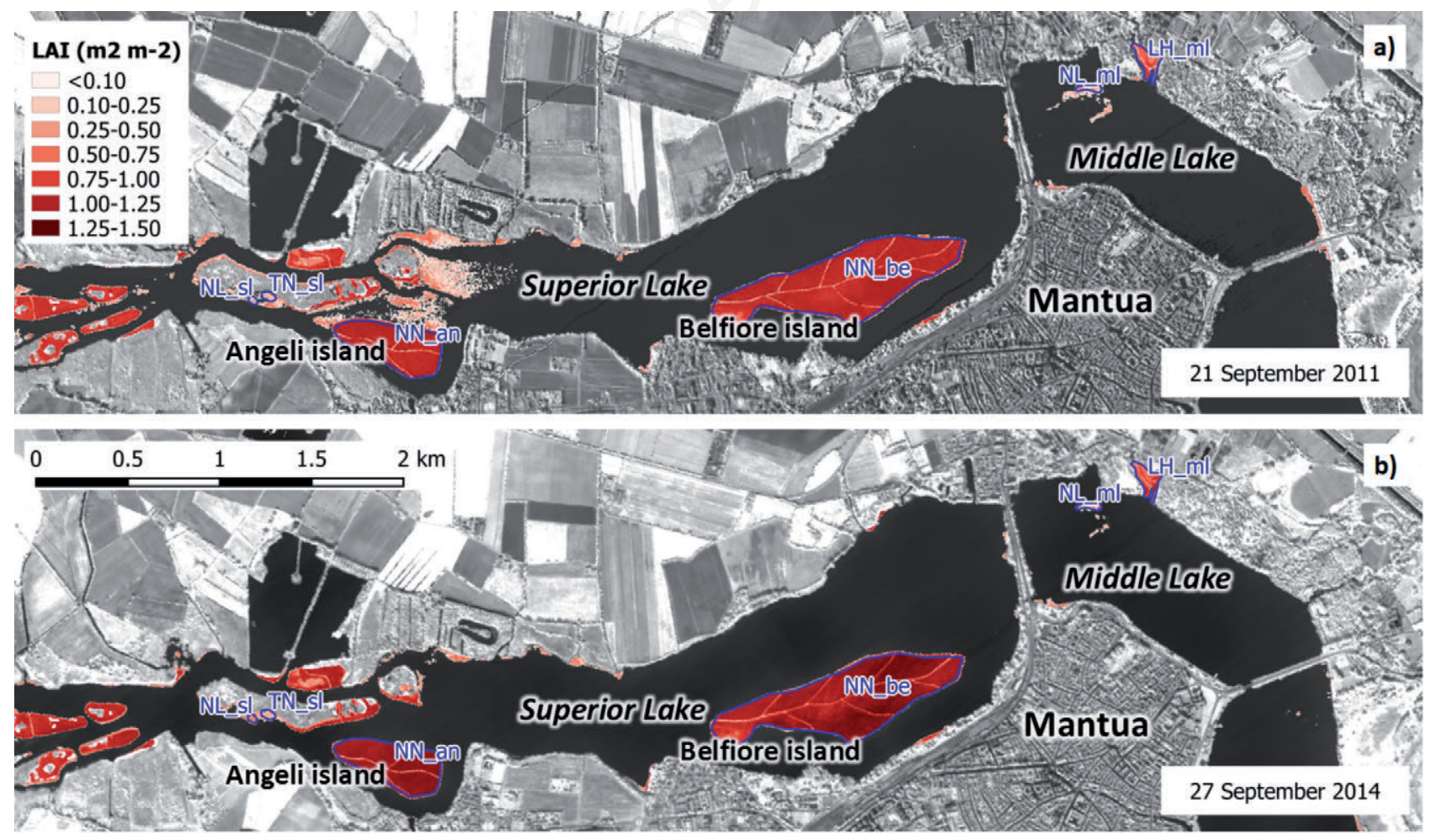

Fig. 7. Comparison of macrophyte LAI mapped using APEX data acquired over Mantua lakes system (detail of Superior Lake and Middle Lake) on 21 September 2011 and on 27 September 2014 over six macrophyte beds, covered by four species of floating and emergent macrophytes. TN, Trapa natans; NL, Nuphar lutea; NN, Nelumbo nucifera; LH, Ludwigia hexapetala. 
lutea beds in 2011 were lower in Superior Lake (35 $\pm 9 \%$, and $0.30 \pm 0.13 \mathrm{~m}^{2} \mathrm{~m}^{-2}$, respectively) compared to Middle Lake $\left(39 \pm 9 \%\right.$, and $0.41 \pm 0.14 \mathrm{~m}^{2} \mathrm{~m}^{-2}$, respectively), but biomass values were equivalent (Fig. $8 \mathrm{c}$ ).

In contrast, MT values for NL stands in 2014 were higher in Superior Lake than in Middle Lake (fC, $50 \pm 8$ and $36 \pm 6 \%$; LAI, $0.55 \pm 0.14$ and $0.33 \pm 0.08 \mathrm{~m}^{2} \mathrm{~m}^{-2}$; Bio$\mathrm{m}_{\text {dry }}, 0.10 \pm 0.02$ and $0.05 \pm 0.02 \mathrm{~kg} \mathrm{~m}^{-2}$ respectively) (Figs. 7 and 8$)$.

\section{DISCUSSION}

\section{Spectral indices as effective proxies} of macrophyte morphological traits

The results achieved in this study build upon those previously reported from research on terrestrial plant communities (Asrar et al., 1989; Goward and Huemmrich, 1992; Gitelson and Merzlyak, 1996; Haboudane et al., 2004) in demonstrating that SIs are straightforward and effective proxies for mapping vegetation morphological traits in
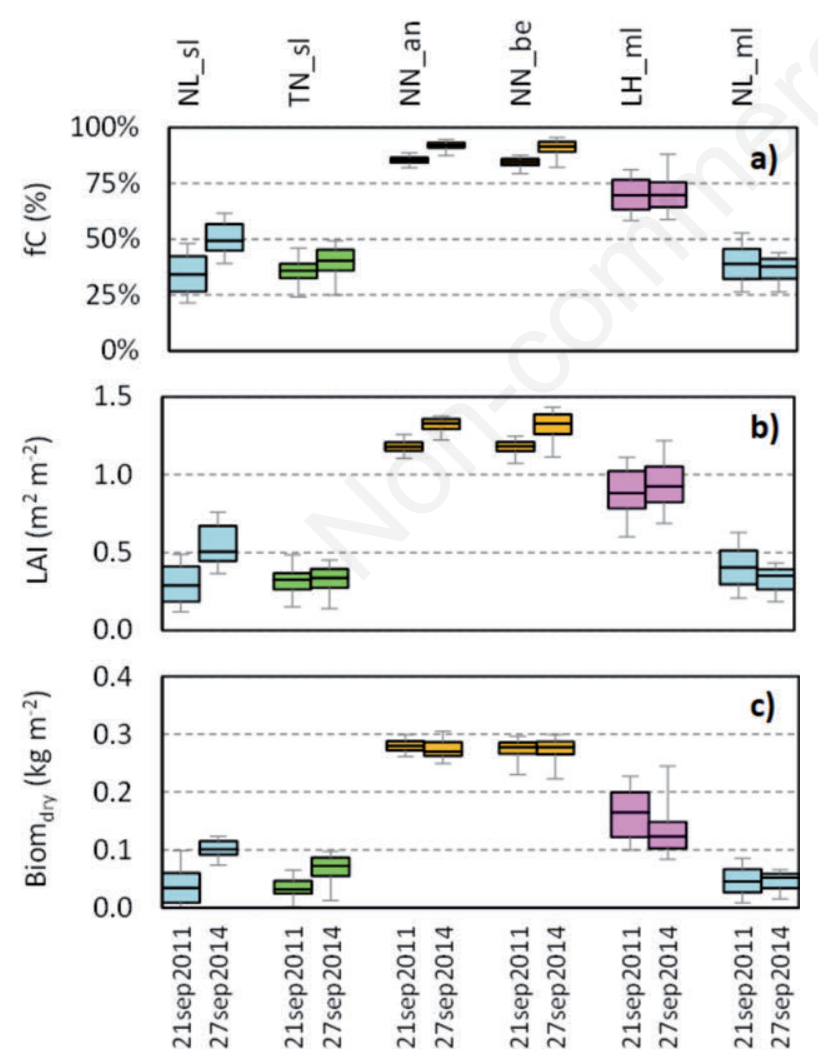

Fig. 8. Box plots (5-25-50-75-95 percentiles) of macrophyte morphological traits mapped from APEX in 2011 and 2014 for the six macrophyte beds identified in Fig. 7: fractional cover (a), LAI (b), and above-water biomass (c). TN, Trapa natans; NL, Nuphar lutea; NN, Nelumbo nucifera; LH, Ludwigia hexapetala. aquatic plant communities too. The strong relationships observed between the SIs and plant morphological traits suggest potential for operational monitoring of aquatic plants in lakes over the ranges (i.e., $0-100 \%$ for $\mathrm{fC}$, $0.0-1.8 \mathrm{~m}^{2} \mathrm{~m}^{-2}$ for LAI, $0.0-0.5 \mathrm{~kg} \mathrm{~m}^{-2}$ for Biom ${ }_{\text {dry }}$ ) and for the species considered in this study. In particular, correlation between SIs and fractional cover or LAI, confirmed the better performance of background adjusted SIs (e.g., GSAVI and EVI) as good linear predictors for canopy density and structure features (Huete et al., 2002; Tian et al., 2005). For above-water biomass, the best performing SIs were those including spectral bands within the red edge region, confirming that spectral response within this wavelength range $(705-710 \mathrm{~nm})$ is particularly sensitive to plant biomass (Hunt et al., 2011). Given the high saturation effect at biomass density higher than 0.5 $\mathrm{kg} \mathrm{m}^{-2}$, this result may not hold for plant communities with particularly dense canopies, but it is reasonable for most of the macrophyte species which can be found in continental and temperate freshwater ecosystems, such as those studied here.

Differently from what observed for fC and LAI, the

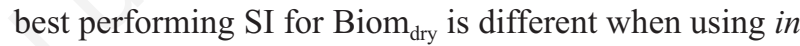
situ or APEX spectra (Tab. 3). This can be attributed to the slightly different performance of atmospheric correction across different spectral ranges (see Supplementary Fig. 1), being CIre less sensitive to atmospheric effects on canopy reflectance compared to MTCI and the other indices, at least for the species and under the environmental conditions investigated.

\section{Nutrient removal capacity in Lake Hídvégi}

In Lake Hídvégi, macrophyte cover was mainly in littoral zones in Basin 2 and 3 (Fig. 1). Basin 4 is closed, with no macrophytes. Among T. natans beds, an anomalous behaviour was observed for $\mathrm{TNb}$ stand in Basin 3, with fractional cover and biomass around $27 \%$ lower than other beds of the same species. T. natans growing in the isolated narrow channel area lying in the eastern part of Basin 3 is in fact subject to very different environmental conditions compared to other stands of the same species growing in Basin 2: deeper water, presence of competitor species (C. demersum and $N$. alba, mainly) and slower water flow all contribute to $\mathrm{TNb}$ stand specific features. T. natans stands growing in Basin 2 are instead probably characterized by more homogeneous water chemistry, current and wind reflected in similar MTs values. During field campaigns in July 2014, water in the southern portion of Basin 2 presented $\sim 3 \mathrm{mg} \mathrm{L}^{-1}$ of total suspended matter and up to $\sim 130 \mathrm{mg} \mathrm{m}^{-3}$ of chlorophyll $a$, which reflect the hypertrophic condition of the Lake Hídvégi (Hatvani et al., 2011; Horváth et al., 2013).

The macrophyte communities in Lake Hídvégi are a fundamental component of the larger Kis-Balaton wetland 
and critical to its ability to promote sedimentation of particulate material and manage nutrient loads carried by the Zala River before it enters Lake Balaton (Istvánovics et al., 2007). Nutrient uptake is performed by submerged macrophytes via leaves and roots, while in floating forms the vast majority of the nutrients are taken up via roots (James et al., 2005; Scheffer and van Nes, 2007). At the end of the vegetative period, following re-mineralization processes in the sediment, most of the nutrients sequestered by macrophytes re-enter the water in a soluble form (Søndergaard et al., 2003; Moss et al., 2005; Jones et al., 2012). The formation of dense macrophytes beds also contributes to the system's filtering capacity by slowing the water flow, favouring the sedimentation of particulate matter (Madsen et al., 2001; Jones et al., 2012). Change in water rheology and oxygen content might result in temporal binding of nutrients (mainly P) in the sediment and reduce its bioavailability (Granéli and Solander, 1988; Søndergaard et al., 2003; Horppila and Nurminen, 2005). In addition, macrophytes can act as substrate for epiphyte communities, which actively assimilate nutrients from the water column (Blindow et al., 2006; Nõges et al., 2010). The accurate mapping of macrophyte morphological traits provides a route to quantifying their capacity for direct nutrient uptake and removal, for example through the conversion of the above-water biomass into an estimate of nutrient storage in leaves or to, at least qualitatively, assess their indirect contribution. The maps derived from APEX show that in July 2014 T. natans meadows in Lake Hídvégi covered a total area of 1.05 $\mathrm{km}^{2}$, corresponding to $\sim 136 \mathrm{t}$ of above-water biomass. In other words, $T$. natans can temporarily store $\sim 3.5 \mathrm{t}$ of nitrogen $(\mathrm{N} ; 2.6 \% \mathrm{~N}$ leaf content, data from Pinardi et al., $2011)$ and $\sim 0.4$ t of $\mathrm{P}(0.3 \% \mathrm{P}$ leaf content measured in July 2014, which was similar to those reported in Pinardi et al., 2011). Due to a much lower areal extent, the contribution from the biomass $(\sim 3.0 \mathrm{t})$ of other floatingleaved species (N. lutea and N. alba) to nutrient storage was negligible compared to T. natans. We must point out that the nutrient stock in T. natans meadows is likely to be an underestimation of the real nutrient uptake because we only considered above-water biomass (e.g., in July above and below water biomass of TN were $60 \%$ and $40 \%$ of total biomass; Pinardi et al., 2011) and without leaf turnover during the whole vegetative period (e.g., by doubling the maximum standing stock; Galanti and Topa Esposito, 1996). If we assume that these values are generally representative of the allocation of biomass above and below water, and an equal allocation of nutrients for above and below water plant parts, then we estimate that the total nutrient storage in T. natans biomass is up to 11.7 $\mathrm{N} t$ and $1.3 \mathrm{Pt}$. According to published works describing nutrient or chemical inflow and water discharge data over time, we calculate a total load for the growing season pe- riod (May-October) of 72-206 t N and 6-13 t P (Szilagyi et al., 1990; Pomogyi, 1993; Tátrai et al., 2000; Hatvani et al., 2011; Horváth et al., 2013; Paulovits et al., 2014). The comparison of nutrient content in macrophyte beds derived from APEX maps with nutrient load inflowing by the Zala River evidenced that about 6-16\% and $10-21 \%$ of $\mathrm{N}$ and $\mathrm{P}$, respectively, can be temporarily stored in $T$. natans biomass.

In general, the second half of July, when the standing stock of floating-leaved species is maximum, is an important period to assess the filter capacity of macrophyte stands in Lake Hídvégi. To exploit the capacity of macrophytes to remove nutrients from the inflow it might be appropriate to perform multiple cuttings during the growing season to maximize nutrient removal, and avoid the risk of hypoxia in shallow waters subject to resuspension and rapid infilling. For instance, biomass cutting and removal actions could be undertaken in late July when the standing stock and $\mathrm{P}$ loads are maximal and growth rates start to slow down (Hatvani et al., 2011), as this would exploit the maximum nutrient assimilative capacity of plants. The after cutting re-growth phase favours assimilative action of the same plants and consequently the increase in their filtration capacity. For not hindering the regrowth and persistence of the species at the same place, a viable management approach that could be suggested is the partial removal of plants or plant parts during the season.

\section{Management of invasive species in Mantua lakes system}

The biomass map of the Mantua lakes system showed higher values in the Superior Lake and in particular in $N$. nucifera meadows around the Angeli and Belfiore islands. In the latter case, the map shows a progressive increase in biomass (from 0.2 to $0.3 \mathrm{~kg} \mathrm{~m}^{-2}$; Fig. 3) from the western to the eastern portion of the island, probably due to different water circulation around the macrophyte bed, which acts as physical barrier and lowers the water velocity at the end of the island compared to the tip (if wind direction is from west to east; Pinardi et al., 2015). Similar patterns were observed on fC and LAI maps.

Maps derived from remote sensing are useful to identify hotspot areas in terms of invasive species with high biomass or macrophyte cover. For example, possible critical areas include: i) littoral zones with low water circulation, such as the south part of the Angeli and Belfiore stands in the Superior Lake (Pinardi et al., 2015), and the east side of the Inferior Lake, and ii) littoral zones where tributaries enter into the lakes, such as the north bank of the three lakes (e.g., L. hexapetala in the Middle Lake). Therefore, local authorities can obtain important information on the localization of critical areas, for example where point sources input might lead to conditions favouring the development of floating macrophyte meadows. 
Remote sensing map products can also be used to identify where cutting action has been performed for extended periods (e.g., the canals free of vegetation created in the two largest islands of $N$. nucifera - Angeli and Belfiore - in the Superior Lake). In addition, it is also possible to exploit the spatial information afforded by remote sensing data to obtain insights into the mechanism of invasion and the subsequent spread of macrophyte species through freshwater systems that might be useful in design future management strategies.

In Mantua system, invasive species ( $N$. nucifera and L. hexapetala) exhibited higher vegetative vigour (in terms of density and biomass) compared to autochthonous floating-leaved species. In order to control invasive species and, in particular, to identify dense macrophyte beds with high biomass, we applied a threshold to LAI map product (LAI $>1 \mathrm{~m}^{2} \mathrm{~m}^{-2}$ ) of the Mantua lakes system (27 September 2014). The macrophyte stands identified (N. nucifera), covered $0.61 \mathrm{~km}^{2}$ resulting in $161 \mathrm{t}$ of biomass. Therefore, by cutting and removing the whole above-water biomass of $N$. nucifera stands, it would be possible to remove $\sim 4.0$ and $\sim 0.3$ t of $\mathrm{N}$ and P respectively from the system (due to scarcity of literature on nutrient elemental content in $N$. nucifera, we applied $2.5 \% \mathrm{~N}$ and $0.2 \%$ P leaf content reported by Longhi et al., 2008 for $N$. lutea in a wetland located in the Province of Mantua). Given the saturation effect on SIs occurring around 0.5 $\mathrm{kg} \mathrm{m}^{-2}$ (Fig. 4c), we must point out that the model used to calculate biomass tends to underestimate actual abovewater biomass. As such, our calculations are an underestimate of the actual amount of nutrients stored in plants.

\section{Multi-temporal analysis (2011 vs 2014) over Mantua lakes system}

Most of the temporal differences in macrophyte MTs showed by multi-temporal maps derived for Mantua lakes system in 2011 and 2014 can be explained with meteorological features characterizing the two growing seasons (Fig. 6).

Lower fC and LAI observed for N. nucifera in 2011, compared to 2014 are probably due to higher wind velocity in 2011 during the period of maximum development of this species (July-August, Fig. 6b). N. nucifera biomass, less sensitive to short term wind anomalies, was in fact similar in both years (Fig. 8c). Lower biomass values of $L$. hexapetala mapped in 2014 are instead possibly due to lower temperature at peak of the growing season, which may have inhibited the full development of plants: from beginning of August to middle of September the mean temperature was $22.0^{\circ} \mathrm{C}$ in 2014 , compared to $25.6^{\circ} \mathrm{C}$ in 2011 (Fig. 6a). On the contrary, increase in biomass from 2011 to 2014 of the T. natans in Superior Lake, a species sensitive to wind conditions especially during late growing season, can be due to the presence of an island located north the stand (Fig. 7), which acts as physical barrier and prevent the effect of wind (Fig. 6b).

In both years, the area covered by invasive species $(\mathrm{NN}+\mathrm{LH})$, i.e., showing $\mathrm{LAI}>1 \mathrm{~m}^{2} \mathrm{~m}^{-2}$, and their mean biomass were in agreement $\left(\sim 0.6 \mathrm{~km}^{2}\right.$ and $\sim 0.27 \mathrm{~kg} \mathrm{~m}^{-2}$, respectively), resulting in a similar quota of nutrients assimilated by plants. Ultimately, even if the time of year is the same (September), the density of invasive species may be different due to particular meteorological conditions (such as wind velocity and air temperature) characterizing the weeks preceding APEX data acquisition.

Late September is a good period to analyse the status of macrophytes, and in particular of $N$. nucifera, before senescence starts. This allows to plan harvesting of invasive species stands, thus avoiding two critical effects: i) excessive organic matter loads settling on the bottom of the lake, and ii) rapid infilling of the system (Pinardi et al., 2011). While control actions are performed, it is fundamental to guarantee a sufficient water discharge to avoid negative effects on the ecosystem (e.g., high oxygen demand, nutrient release due to sediment resuspension).

\section{CONCLUSIONS}

Macrophyte products derived by remote sensing techniques allow to map morphological traits of different species that colonize shallow lakes and wetlands, in terms of above-water biomass and density (fractional cover and LAI), as well as surface area. These mapping products can be an effective tool for efficient and sustainable management of shallow water environments, with relevance to filter capacity assessment (i.e., nutrient and particulate matter retention) and invasive species control (i.e., harvesting). Reliable biomass estimates at maximum standing stock allow the quantification of the nutrient load assimilated by macrophytes and provide detailed and spatialized input to $\mathrm{N}$ and $\mathrm{P}$ budgets at watershed level, as we demonstrate here for the Lake Hídvégi case study.

Macrophyte density and LAI maps, as the case of Mantua lakes system, can be used to efficiently identify hotspot areas where invasive species management is most needed (e.g., biomass harvesting).

These actions can avoid the establishment of areas characterized by water stagnation, prevent algal blooms, and/or further development of floating or emergent macrophytes. With remotely sensed maps of macrophyte morphological traits it is possible for water management institutions or local authorities to promptly identify the priority areas of action both for conservation and economic purposes. In addition, estimating the amount of biomass that could be removed and destined for reuse is also important in terms of economic value: e.g., for proper planning and energy generation purposes. 


\section{ACKNOWLEDGMENTS}

This study has received funding from the European Community's Seventh Framework Programme [FP7/2007-2013] under grant agreement no. 606865 (INFORM). INFORM project funded the APEX data acquisition of 19 July 2014 over Lake Hídvégi. EuFAR provided support and funding for APEX data acquisition in Mantua on 21 September 2011 (Hablakes project) and on 27 September 2014 (HYPPOS project). Part of the work has been carried out in the framework of the Agreement on Scientific Cooperation between the Hungarian Academy of Sciences and the Consiglio Nazionale delle Ricerche (MacroSense project). The authors must acknowledge the precious work of Mátyás Présing, who passed away in 2015, for having made possible the Lake Hídvégi 2014 fieldwork. Many thanks to Mauro Musanti (CNR-IREA) and Federica Braga (CNR-ISMAR) for their help during Mantua lakes system and Lake Hídvégi 2014 fieldwork, and to the Balaton Limnological Institute of the Hungarian Academy of Sciences (Tihany, Hungary) for the logistic support.

\section{REFERENCES}

Adam E, Mutanga O, Rugege D, 2010. Multispectral and hyperspectral remote sensing for identification and mapping of wetland vegetation: a review. Wetl. Ecol. Manag. 18:281-296.

Aspila KI, Agemian H, Chau ASY, 1976. A semi-automated method for the determination of inorganic, organic and total phosphate in sediments. Analyst 101:187-197.

Asrar G, Myneni RB, Li Y, Kanemasu ET, 1989. Measuring and modeling spectral characteristics of a tallgrass prairie. Remote Sens. Environ. 27:143-155.

Bannari A, Morin D, Bonn F, Huete AR, 1995. A review of vegetation indices. Remote Sens. Rev. 13:95-120.

Barnes EM, Clarke TR, Richards SE, Colaizzi PD, Haberland J, Kostrzewski M, Moran MS, 2000. Coincident detection of crop water stress, nitrogen status and canopy density using ground based multispectral data. In: Proceedings 5th International Conference on Precision Agriculture, Bloomington, pp. 16-19.

Birk S, Ecke F, 2014. The potential of remote sensing in ecological status assessment of coloured lakes using aquatic plants. Ecol. Indic. 46:398-406.

Blindow I, Hargeby A, Meyercordt J, Schubert H, 2006. Primary production in two shallow lakes with contrasting plant form dominance: A paradox of enrichment? Limnol. Oceanogr. 51:2711-2721.

Boerema A, Schoelynck J, Bal K, Vrebos D, Jacobs S, Staes J, Meire P, 2014. Economic valuation of ecosystem services, a case study for aquatic vegetation removal in the Nete catchment (Belgium). Ecosyst. Serv. 7:46-56.

Bolpagni R, Laini A, Soana E, Tomaselli M, Nascimbene J, 2015. Growth performance of Vallisneria spiralis under oligotrophic conditions supports its potential invasiveness in mid-elevation freshwaters. Weed Res. 55:185-194.
Bolpagni R, Pierobon E, Longhi D, Nizzoli D, Bartoli M, Tomaselli M, Viaroli P, 2007. Diurnal exchanges of $\mathrm{CO}_{2}$ and $\mathrm{CH}_{4}$ across the water-atmosphere interface in a water chestnut meadow (Trapa natans L.). Aquat. Bot. 87:43-48.

Bolpagni R, Piotti A, 2016. The importance of being natural in a human-altered riverscape: role of wetland type in supporting habitat heterogeneity and the functional diversity of vegetation. Aquat. Conserv. 26:1168-1183.

Bresciani M, Stroppiana D, Fila G, Montagna M, Giardino C, 2009. Monitoring reed vegetation in environmentally sensitive areas in Italy. Ital. J. Remote Sens. 41:125-137.

Broge NH, Leblanc E, 2001. Comparing prediction power and stability of broadband and hyperspectral vegetation indices for estimation of green leaf area index and canopy chlorophyll density. Remote Sens. Environ. 76:156-172.

Bukata RP, 2005. Satellite monitoring of inland and coastal water quality: retrospection, introspection, future directions. CRC Press, Boca Raton: 272 pp.

Castaldelli G, Soana E, Racchetti E, Vincenzi F, Fano EA, Bartoli M, 2015. Vegetated canals mitigate nitrogen surplus in agricultural watersheds. Agr. Ecosyst. Environ. 212: 253-262.

Chen JM, 1996. Evaluation of vegetation indices and a modified simple ratio for boreal applications. Can. J. Remote Sens. 22:229-242.

Dash J, Curran PJ, 2004. The MERIS terrestrial chlorophyll index. Int. J. Remote Sens. 25:5403-5413.

De Haan JF, Hovenier JW, Kokke JMM, Van Stokkom HTC, 1991. Removal of atmospheric influences on satellite-borne imagery: a radiative transfer approach. Remote Sens. Environ. 37:1-21.

Dinka M, Ágoston-Szabó E, Urbanc-Berčič O, Germ M, ŠrajKržič N, Gaberščik A, 2008. Reed stand conditions at selected wetlands in Slovenia and Hungary, p. 1-12. In: J. Vymazal (ed.), Wastewater treatment, plant dynamics and management in constructed and natural wetlands. Springer, Doirdrecht.

Dömötörfy Z, Reeder D, Pomogyi P, 2003. Changes in the macrovegetation of the Kis-Balaton Wetlands over the last two centuries: a GIS perspective. Hydrobiologia 506:671-679.

Dudgeon D, Arthington AH, Gessner MO, Kawabata ZI, Knowler DJ, Lévêque C, Sullivan CA, 2006. Freshwater biodiversity: importance, threats, status and conservation challenges. Biol. Rev. 81:163-182.

European Union, 2000. Directive 2000/60/EC of the European Parliament and of the Council of 23 October 2000 establishing a framework for Community action in the field of water policy. OJ L 327, 22/12/2000, pp. 1-73.

Galanti G, Topa Esposito A, 1996. The invasive capacity of water chestnut as shown in the management of a natural population in Lago di Candia. Lake Reserv. Manage. 2:31-36.

Gege P, Fries J, Haschberger P, Schötz P, Schwarzer H, Strobl P, Suhr B, Ulbrich G, Vreeling WJ, 2009. Calibration facility for airborne imaging spectrometers. ISPRS J. Photogramm. 64:387-397.

Gitelson AA, Keydan GP, Merzlyak MN, 2006. Three-band model for noninvasive estimation of chlorophyll, carotenoids, and anthocyanin contents in higher plant leaves. Geophys. Res. Lett. 33:L11402.

Gitelson AA, Merzlyak MN, 1994. Quantitative estimation of 
chlorophyll-a using reflectance spectra: Experiments with autumn chestnut and maple leaves. J. Photoch. Photobio B 22:247-252.

Gitelson AA, Merzlyak MN, 1996. Signature analysis of leaf reflectance spectra: algorithm development for remote sensing of chlorophyll. J. Plant Physiol. 148:494-500.

Gobron N, Pinty B, Verstraete MM, Widlowski JL, 2000. Advanced vegetation indices optimized for up-coming sensors: Design, performance, and applications. IEEE T. Geosci. Remote 38:2489-2505.

Goodwin K, Caraco N, Cole J, 2008. Temporal dynamics of dissolved oxygen in a floating-leaved macrophyte bed. Freshwater Biol. 53:1632-1641.

Goward SN, Huemmrich KF, 1992. Vegetation canopy PAR absorptance and the normalized difference vegetation index: an assessment using the SAIL model. Remote Sens. Environ. 39:119-140.

Granéli W, Solander D, 1988. Influence of aquatic macrophytes on phosphorus cycling in lakes. Hydrobiologia 170:245-266.

Haboudane D, Miller JR, Pattey E, Zarco-Tejada PJ, Strachan IB, 2004. Hyperspectral vegetation indices and novel algorithms for predicting green LAI of crop canopies: Modeling and validation in the context of precision agriculture. Remote Sens. Environ. 90:337-352.

Hatvani IG, Kovács J, Kovács IS, Jakusch P, Korponai J, 2011. Analysis of long-term water quality changes in the Kis-Balaton Water Protection System with time-series, cluster analysis and Wilks' lambda distribution. Ecol. Eng. 37:629-635.

Hestir EL, Khanna S, Andrew ME, Santos MJ, Viers JH, Greenberg JA, Rajapakse SR, Ustin SL, 2008. Identification of invasive vegetation using hyperspectral remote sensing in the California Delta ecosystem. Remote Sens. Environ. 112:40344047.

Horppila J, Nurminen L, 2005. Effects of different macrophyte growth forms on sediment and $\mathrm{P}$ resuspension in a shallow lake. Hydrobiologia 545:167-175.

Horváth H, Mátyás K, Süle G, Présing M, 2013. Contribution of nitrogen fixation to the external nitrogen load of a water quality control reservoir (Kis-Balaton Water Protection System, Hungary). Hydrobiologia 702:255-265.

Huete AR, 1988. A soil-adjusted vegetation index (SAVI). Remote Sens. Environ. 25:295-309.

Huete A, Didan K, Miura T, Rodriguez EP, Gao X, Ferreira LG, 2002. Overview of the radiometric and biophysical performance of the MODIS vegetation indices. Remote Sens. Environ. 83:195-213.

Hunt ER, Daughtry CST, Eitel JU, Long DS, 2011. Remote sensing leaf chlorophyll content using a visible band index. Agron. J. 103:1090-1099.

Hunter PD, Gilvear DJ, Tyler AN, Willby NJ, Kelly A, 2010. Mapping macrophytic vegetation in shallow lakes using the Compact Airborne Spectrographic Imager (CASI). Aquat. Conserv. 20:717-727.

Istvánovics V, Clement A, Somlyódy L, Specziár A, László G, Padisák J, 2007. Updating water quality targets for shallow Lake Balaton (Hungary), recovering from eutrophication. Hydrobiologia 581:305-318.

Jacobs AE, Harrison JA, 2014. Effects of floating vegetation on denitrification, nitrogen retention, and greenhouse gas production in wetland microcosms. Biogeochemistry 119:51-66.
James C, Fisher J, Russell V, Collings S, Moss B, 2005. Nitrate availability and hydrophyte species richness in shallow lakes. Freshwater Biol. 50:1049-1063.

Jeppensen E, Jensen JP, Søndergaard M, Lauridsen T, Pedersen LJ, Jensen L, 1997. Top-down control in freshwater lakes: the role of nutrient state, submerged macrophytes and water depth. Hydrobiologia 342/343:151-164.

Jones JI, Collins AL, Naden PS, Sear DA, 2012. The relationship between fine sediment and macrophytes in rivers. River Res. Appl. 28:1006-1018.

Jordan SJ, Stoffer J, Nestlerode JA, 2011. Wetlands as sinks for reactive nitrogen at continental and global scales: A metaanalysis. Ecosystems 14:144-155.

Kosten S, Jeppesen E, Huszar VLM, Mazzeo N, Van Nes EH, Peeters ETHM, Scheffer M, 2011. Ambiguous climate impacts on competition between submerged macrophytes and phytoplankton in shallow lakes. Freshwater Biol. 56:15401553.

Kovács J, Hatvani IG, Korponai J, Kovácsné SzI, 2010. Morlet wavelet and auto-correlation analysis of long term data series of the Kis-Balaton Water Protection System (KBWPS). Ecol. Eng. 36:1469-1477.

Longhi D, Bartoli M, Viaroli P, 2008. Decomposition of four macrophytes in wetland sediments: Organic matter and nutrient decay and associated benthic processes. Aquat. Bot. 89:303-310.

Maccioni A, Agati G, Mazzinghi P, 2001. New vegetation indices for remote measurement of chlorophylls based on leaf directional reflectance spectra. J. Photoch. Photobio. B 61:52-61.

Madsen JD, Chambers PA, James WF, Koch EW, Westlake DF, 2001. The interaction between water movement, sediment dynamics and submersed macrophytes. Hydrobiologia 444:71-84

Mckee D, Hatton K, Eaton JW, Atkinson D, Atherton A, Harvey I, Moss B, 2002. Effects of simulated climate warming on macrophytes in freshwater microcosm communities. Aquat. Bot. 74:71-83.

MEA - Millennium Ecosystem Assessment, 2005. Ecosystems and human well-being: wetlands and water. World Resources Institute, Washington, DC: 68 pp.

Metzger MJ, Rounsevell MDA, Acosta-Michlik L, Leemans R, Schröter D, 2006. The vulnerability of ecosystem services to land use change. Agr Ecosyst. Environ. 114:69-85.

Moss B, Barker T, Stephen D, Williams AE, Balayla DJ, Beklioglu M, Carvalho L, 2005. Consequences of reduced nutrient loading on a lake system in a lowland catchment: deviations from the norm? Freshwater Biol. 50:1687-1705.

Nõges T, Luup H, Feldmann T, 2010. Primary production of aquatic macrophytes and their epiphytes in two shallow lakes (Peipsi and Võrtsjärv) in Estonia. Aquat. Ecol. 44:83-92.

Palmer SC, Kutser T, Hunter PD, 2015. Remote sensing of inland waters: Challenges, progress and future directions. Remote Sens. Environ. 157:1-8.

Paulovits G, Ferincz Á, Staszny Á, Weiperth A, Tátrai I, Korponai J, Mátyás K, Kováts N, 2014. Long-term changes in the fish assemblage structure of a shallow eutrophic reservoir (Lake Hídvégi, Hungary), with special reference to the exotic Carassius gibelio. Int. Rev. Hydrobiol. 99:373-381.

Penuelas J, Gamon JA, Griffin KL, Field CB, 1993. Assessing 
community type, plant biomass, pigment composition, and photosynthetic efficiency of aquatic vegetation from spectral reflectance. Remote Sens. Environ. 46:110-118.

Pinardi M, Bartoli M, Longhi D, Viaroli P, 2011. Net autotrophy in a fluvial lake: the relative role of phytoplankton and floating-leaved macrophytes. Aquat. Sci. 73:389-403.

Pinardi M, Fenocchi A, Giardino C, Sibilla S, Bartoli M, Bresciani $\mathrm{M}, 2015$. Assessing potential algal blooms in a shallow fluvial lake by combining hydrodynamic modelling and remote-sensed images. Water 7:1921-1942.

Poff NL, Brinson MM, Day JW, 2002. Aquatic ecosystems and global climate change. Pew Center on Global Climate Change, Arlington: $44 \mathrm{pp}$.

Pomogyi P, 1993. Nutrient retention by the Kis-Balaton water protection system. Hydrobiologia 251:309-320.

Ribaudo M, Greene C, Hansen L, Hellerstein D, 2010. Ecosystem services from agriculture: steps for expanding markets. Ecol. Econ. 69:2085-2092.

Rouse Jr. J, Haas RH, Schell JA, Deering DW, 1974. Monitoring vegetation systems in the Great Plains with ERTS, p. 309317. In: C.F. Stanley, E.P. Mercanti and M.A. Becker (eds.), Third ERTS-1 Symp. Vol. 1. NASA Special Publication, Washington.

Schaeffer BA, Schaeffer KG, Keith D, Lunetta RS, Conmy R, Gould RW, 2013. Barriers to adopting satellite remote sensing for water quality management. Int. J. Remote Sens. 34:7534-7544.

Schaepman ME, Jehle M, Hueni A, D’Odorico P, Damm A, Weyermann J, Lenhard K, 2015. Advanced radiometry measurements and Earth science applications with the Airborne Prism Experiment (APEX). Remote Sens. Environ. 158:207-219.

Scheffer M, Van Nes EH, 2007. Shallow lakes theory revisited: various alternative regimes driven by climate, nutrients, depth and lake size. Hydrobiologia 584:455-466.

Schriver P, Bogestrand J, Jeppensen E, Sondergaard M, 2005. Impact of submerge macrophytes on fish-zooplankton interactions: large-scale enclose experiments in a shallow eutrophic lake. Freshwater Biol. 33:255-270.

Silva TS, Costa MP, Melack JM, Novo EM, 2008. Remote sensing of aquatic vegetation: theory and applications. Environ. Monit. Assess. 140:131-145.

Søndergaard M, Jensen JP, Jeppesen E, 2003. Role of sediment and internal loading of phosphorus in shallow lakes. Hydrobiologia 506:135-145.

Steffen W, Sanderson RA, Tyson PD, Jäger J, Matson PA, Moore B III, Oldfield F, Richardson K, Schellnhuber HJ, Turner BL II, Wasson RJ, 2006. Global change and the earth system: a planet under pressure. Springer, Berlin: $336 \mathrm{pp}$.

Stratoulias D, Balzter H, Zlinszky A, Tóth VR, 2015. Assessment of ecophysiology of lake shore reed vegetation based on chlorophyll fluorescence, field spectroscopy and hyperspectral airborne imagery. Remote Sens. Environ. 157:72-84.

Szilagyi F, Somlyódy L, Koncsos L, 1990. Operation of the KisBalaton reservoir: evaluation of nutrient removal rates. Hydrobiologia 191:297-306.

Tátrai I, Mátyás K, Korponai J, Paulovits G, Pomogyi P, 2000. The role of the Kis-Balaton Water Protection System in the control of water quality of Lake Balaton. Ecol. Eng. 16:73-78.

Tian YC, Zhu Y, Cao WX, 2005. Monitoring soluble sugar, total nitrogen and its ratio in wheat leaves with canopy spectral reflectance. Act. Agron. Sin. 31:355-360.

Tomaselli M, Gualmini M, Spettoli O, 2000. [La vegetazione della Riserva Naturale delle Valli del Mincio. Parma (IT)]. [Article in Italian]. Collana Annali Facoltà di Scienze Matematiche Fisiche e Naturali dell'Università di Parma: 90 pp.

Tou JT, Gonzalez RC, 1974. Pattern recognition principles. Addison-Wesley Publishing, London: 378 pp.

Tucker CJ, Elgin JH, McMurtrey JE, Fan CJ, 1979. Monitoring corn and soybean crop development with hand-held radiometer spectral data. Remote Sens. Environ. 8:237-248.

Villa P, Laini A, Bresciani M, Bolpagni R, 2013. Remote sensing approach to monitor the conservation status of lacustrine Phragmites australis beds. Wetl. Ecol. Manag. 21:399-416.

Villa P, Mousivand A, Bresciani M, 2014. Aquatic vegetation indices assessment through radiative transfer modeling and linear mixture simulation. Int. J. Appl. Earth Obs. 30:113-127.

Villa P, Bresciani M, Bolpagni R, Pinardi M, Giardino C, 2015. A rule-based approach for mapping macrophyte communities using multi-temporal aquatic vegetation indices. Remote Sens. Environ. 171:218-233.

Wetzel RG, 1992. Wetlands as metabolic gates. J. Great Lakes Res. 18:529-532.

Wu C, Niu Z, Tang Q, Huang W, Rivard B, Feng J, 2009. Remote estimation of gross primary production in wheat using chlorophyll-related vegetation indices. Agr. Forest Meteorol. 149:1015-1021. 